\title{
Gogoeta batzuk Naming and Necessityri buruz
}

\author{
Reflections on Naming and Necessity
}

\author{
Michael DeVITT* \\ Graduate Center (City University of New York)
}

Kepa Kortak ingelesetik itzulia.

LABURPENA. Artikulu honek Naming and Necessityren berrogeigarren urteurrena ospatzen $\mathrm{du}$, eta batera biltzen ditu urteetan zehar lan horri buruz egin ditudan gogoeta batzuk. Nire ustez gaizki ulertu diren liburuko alderdietan jartzen du arreta, edo atzeman ez direnetan, edo oker baztertu direnetan edo, besterik gabe, azpimarratzea merezi dutenetan. Hizkuntzaren filosofiarekin hasten da, lehendabizi erreferentziaren deskripzio-teorien kontrako Kripkeren argudiorik indartsuena, "ezjakite eta akatsa"ren argudioa, eztabaidatuz. Gero Kripkeren "irudi hobea", kausal-historikoa eta zurruntasunari buruzko bere eztabaida hartzen ditu aintzat, eta, azkenik, "erreferentzia zuzena", Kripkeri oker egotzitako doktrina onargaitza. Gainerakoak biologia- eta kimika-klaseei eta banakoei buruz Kripkek proposatu dituen doktrina esentzialistez dihardu. Zientziaren filosofo batzuek zorrotz kritikatu dituzte doktrina horiek. Nik uste dut dagozkien zientziek Kripkeren alde egiten dutela, ez kritikoen alde.

GAKO-HITZAK: deskripzio-teoriak; teoria kausal-historikoak; zurruntasuna; erreferentzia zuzena; esentzialismo biologikoa; esentzialismo kimikoa; esentzialismo indibiduala.

\begin{abstract}
This paper celebrates the fortieth anniversary of Naming and Necessity by gathering together some reflections I have made on that work over the years. The paper focuses on aspects of the book that I think have been misunderstood, overlooked, mistakenly rejected, or simply merit more emphasis. The paper starts with the philosophy of language, first discussing Kripke's most powerful argument against description theories of reference, the "ignorance and error" argument. It then considers Kripke's causal-historical "better picture", his discussion of rigidity, and finally, "direct reference", an implausible doctrine that has been wrongly attributed to Kripke. The rest of the paper is concerned with essentialist doctrines that Kripke has urged about biological kinds, chemical kinds, and individuals. These doctrines have been trenchantly criticized by some philosophers of science. I think that the relevant sciences support Kripke, not the critics.
\end{abstract}

KEYWORDS: description theories; causal-historical theories; rigidity; direct reference; biological essentialism; chemical essentialism; individual essentialism.

\footnotetext{
* Harremanetan jartzeko / Corresponding author: Michael Devitt. Graduate center, City University of New York, 365 Fifth Avenue, New York, NY 10016 - mdevitt@gc.cuny.edu - https://orcid.org/0000-0003-2298-2490

Nola aipatu / How to cite: Devitt, Michael (2021). "Gogoeta batzuk Naming and Necessityri buruz", Gogoa, 22, 63-92. (https://doi.org/10.1387/gogoa.22599).

Jasoa: 2020-XI-19. Onartua: 2021-II-20. Aurrena online argitaratua: 2021-III-15.

ISSN 1577-9424 - eISSN 2444-3573 / (c) 2021 UPV/EHU
}

(c) (i) Lan hau Creative Commons Aitortu 4.0 Nazioartekoaren

lizentziapean dago 


\section{Sarrera}

Honezkero klasikoa den Saul Kripkeren Naming and Necessity (1980) liburuaren berrogeigarren urteurrena ospatzeko eskatu didate artikulu hau. Baina berrogeita hamar urte baino gehiago da liburu horretako ideien berri izan nuela. 1967ko iraila zen, eta Harvardera iritsi berria nintzen, bertako doktorego-programara. Kripkek eman zuen graduko klase batera joan nintzen, eta han aurkeztu zituen ideia horiek lehen aldiz. ${ }^{1}$ Ideia gehienen hurrengo bertsioa hitzaldi gisa aurkeztu zuen Princetonen, 1970ean, eta artikulu gisa argitaratu, "Naming and Necessity" (1972) gisa. Titulu bereko liburu gisa argitaratu zen azkenik.

Hitzaldi haiek — horren argiak, horren bikainak— eragin sakona izan zuten nigan. Ororen buru, izen propioei buruzko Kripkeren ikuskera nire doktore-tesiaren inspirazio nagusia izan zen, "The Semantics of Proper Names: A Causal Theory" (1972). ${ }^{2}$ Lan horretan eta geroagoko batzuetan (1974; 1981a,b; 2015), erreferentzia singularraren teoria kausal-historiko "naturalista" bat osatzen saiatu nintzen. Eta, jakina, Kripke ez da naturalista; "besaulki"ko filosofo handia da, bere intuizioetan oinarritzeagatik ezaguna. Hala ere, nire ikuskera naturalistatik ere, horrenbesterekin asmatu zuen! Artikulu honetako gai inplizitua da hau: maiz pentsatu izan dut Kripkek "errealitaterako sarbide pribilegiatua" duela.

Nire lanetan, han-hemenka, gehienbat sakabanatuta azaldu diren $\mathrm{Na}$ ming and Necessityri buruzko gogoeta batzuk bilduko ditut artikulu honetan. Gaizki ulertu, ikusi ez, oker baztertu direla edo, besterik gabe, enfasi gehiago merezi dutela uste dudan liburuaren alderdietan jarriko dut arreta. ${ }^{3} 2$. atalean, erreferentziari buruzko deskripzio-teorien aurkako Kripkeren argudiorik indartsuena eztabaidatuko dut, "ezjakite eta akatsa"ren argudioa. 3. atalean, alternatiba kausal-historikoari eta erreferentzia-mailegatzeari buruz jardungo dut. 4. atalean, zurruntasuna eta deskripzio-teoriak hartzen ditut gogoan, eta, 5.ean, erreferentzia zuzena. Atal horiek nagusiki hizkuntzaren filosofiari buruzkoak dira, hortaz. Gainerakoak esentzialismoari buruzkoak dira: biologia-klaseen esentzialismoa, 6. atalean; kimika-klaseena, 7. atalean; banakoena, 8. atalean.

\footnotetext{
${ }^{1}$ Klaseko erdiak-edo ginen graduatutako ikasleak. Orduko nire oharrak Saul Kripke Zentroko artxiboetan daude.

2 Andrea Bianchik (2020) dio izenei buruzko nire teoria "Donnellanek eskainitako ikuskera kausal alternatiboaren garapen gisa hartu beharko litzatekeela" eta ez Kripkerenaren gisa. Zinez, Kripke izan zen nire teorian eragina izan zuena; nire tesia ia osatuta zegoen izen propioei buruzko Donnellanen (1972) artikulua irakurri nuenerako. Baina deskripzio definituei buruzko nire ikuskerak $(1972,1974,1981 b, 2004)$ bazuen Donnellanenaren $(1966,1968)$ eragin handia.

3 Ez dut eztabaidatuko, hortaz, Kripkeren demostrazio bizia, beharrezkoa denaren eta (ustez) a priori ezaguna denaren artean bereiztearen garrantziarena. Garrantzia orain, oro har, onartua dagoela uste dut.
} 


\section{Deskripzio-teoriak eta Ezjakitea eta Akatsa}

Ohikoa da pentsatzea termino baten errealitatearekiko erreferentziaerlazioa dela bere esanahiaren muina. Izen propio baten kasuan erlazio hori objektu jakin batekikoa da. Oinarrizko galdera hau sortzen du horrek: zeren arabera erreferitzen du izenak objektu hori? Erreferentziaren teoria batek galdera horri erantzun nahi dio. 1970eko hamarkada arte, erantzun ezagun guztiak deskripzio-teoriak ziren modu batez ala bestez. Hala, Frege-Russell teoria "klasiko"aren arabera, izen baten erreferentzia hiztun konpetenteek harekin lotzen duten deskripzio batek mugatzen du; "Gödel"en kasuan, adibidez, "aritmetikaren ez-osotasuna frogatu zuen pertsona" deskripzioak; "Jonas"en kasuan, Jonasen istorio biblikoaren puntu nagusiak jasotzen dituen batek. Kripkek kritika suntsigarriak diruditenak egin zizkien hainbat deskripzioteoriari, klasikoari barne. Eta "irudi hobe" (94 [51-52]) $)^{4}$ alternatiboa proposatu zuen, zeinaren arabera izen baten erreferentzia izenaren sarreraraino atzera hedatzen den "erreferentzia-mailegatze" sail batek mugatzen baitu; erreferentzia mugatzea kontu "kausal-historikoa" da. Horrela hasi zen erreferentziaren teoriaren iraultza.

Izenei buruzko deskripzio-teorien Kripkeren ezeztatzeak hiru argudio dauzka, Kim Sterelnyk eta biok, gure testuliburuan, "Nahi Gabeko Beharrezkotasuna", "Galdutako Zurruntasuna" eta "Ezjakitea eta Akatsa" deitu genituenak (1999: 48-59). Kripkeren Ezjakite eta Akatsaren argudioa, eta Keith Donnellanen (1972) antzeko argudio bat, berriak ziren erabat. Kripkeren Galdutako Zurruntasunaren argudioa gertu samar zegoen erabat berria izatetik. ${ }^{5}$ Kripkeren errefutazioari emandako berehalako erantzunek Galdutako Zurruntasunean jarri zuten arreta, baina niri beti iruditu zitzaidan Ezjakitea eta Akatsa zela argudio benetan boteretsua. Izan ere, oso gertu dago "behin betiko" argudio batetik, filosofian halakorik aurkitzea posible bada, eta Kripkek hizkuntzaren filosofiari egindako bi ekarpen itzeletako bat da. Horrekin hasiko naiz. Egingo ditut Galdutako Zurruntasunari buruzko ohar batzuk, 4. atalean. Eta pasaeran soilik aipatuko dut Nahi Gabeko Beharrezkotasuna.

Deskripzio-teoriak erraz interpretatzen dira, estu, esanahiaren teoria gisa: izen propio baten esanahia hiztun konpetenteek izenarekin lotzen duten deskripzioak adierazten du, erreferentea identifikatzen duen deskripzioak.

4 Azaldu gabeko aipu guztiak Naming and Necessitykoak dira. [Ale honetako itzulpenari dagozkionean, emango ditut orrialde horiek ere kako zuzenen artean].

5 Deskripzioen "sorta"-teoria modernoaren kontrako Nahi Gabeko Beharrezkotasunaren argudioa berria zen, baina teoria klasikoaren kontrakoa ezaguna zen ordurako, eta sorta-teoriaren motibazioetako bat zen; ikus Searle (1958). Teoria klasikoaren problema ezaguna zen, esate baterako, "Aristoteles"ekin lotzen dugun deskripzio bakar orok propietate bat hautatzen duela, zitekeena zena Aristotelesek ez edukitzea. Sorta-teoriaren aurkako Kripkeren puntu berria zen: "Aristotelesi egotzi ohi zaizkion gauza gehienak bazitekeen Aristotelesek inondik ere egin ez izatea" (61). 
Interpretazio ahulago batek ez du esanahiari buruzko baieztapenik egiten: izenari lotzen zaion deskripzioak ez du erreferentea identifikatu besterik egiten. Kripkek erakutsi zuen, hainbat kasu errealen bidez, izen askoren erabiltzaile gehienak ez direla gai intuitiboki erreferenteak direnak taxuz identifikatzen dituzten deskripzio egokiak emateko. Izenei lotutako deskripzioek, beraz, ez dute mugatzen bere erreferentea. Ez dute adierazten, hortaz, erreferentea mugatzen duten esanahirik. Hala, Zizeron, Katilina, Feynman eta Einsteinen izenen erabiltzaile gehienak ezjakinegiak dira pertsona horien deskripzio identifikatzaileak emateko (80-83 [42-44]). Areago, Peano, Einstein eta Kolonen izenen erabiltzaile askok pertsona horiei buruz faltsuak diren deskripzioak lotzen dizkiete (84-85 [44-45]). Baina Kripkeren intuizioek diote erabiltzaile horiek, hala ere, arrakastaz designatzen dituztela pertsona horiek beren izenekin.

Garrantzitsua da ohartzea kasu horiek kontu arrunta direla; ez dira kontrafaktiko, hipotetiko, fikziozko edo inola ere bitxi (Kripkeren Gödel kasua $(83-84 \text { [44] })^{6}$ edo, zer esanik ez, Hilary Putnamen $(1973,1975)$ "Lur Biki"aren kasua badiren moduan). Horietan oinarrituta oso erraza da kasu zenbatezinak ekartzea, horiek bezain arrunt, eta guztiek intuizio berbera eraginez; hiztunaren ezjakitea edo akatsa gorabehera, izen baten erabilpenak objektu bat designatzen duela, alegia. ${ }^{7}$ Intuizio horiek oso indartsuak dira horiek baztertzea honako hau erabakitzea baita: ia aho guztietatik ateratzen diren izen askok huts egiten dutela designatu beharko luketena designatzen. Eta, nik dakidala, ez dago intuizio horiek baztertu dituen filosoforik. ${ }^{8}$

Hori ez da esatea argudio horren aurrean filosofoek izenen deskripzioteoriak baztertu egin dituztela. Asko saiatu dira Ezjakitea eta Akatsa saihestuko luketen deskripzio-teoria berriak asmatzen. Duela gutxi, horietako batzuen laburpen kritikoa egin du Panu Raatikanenek (2020), proposamenik aipagarrienarena barne:

David Lewisek (1984), Fred Kroonek (1987) eta Frank Jacksonek (1998) hobetsitako "deskriptibismo kausala" (...) hiztunek honelako deskripzio bat lotzen diote " $N$ " izen bati, "' $N$ ' izenaren nire oraingo erabilera honekin $R$ erlazioa duen entitatea", eta deskripzio horrek mugatzen

\footnotetext{
${ }^{6}$ Horregatik, lastima da Kripkeren kritikoek, Machery eta bestek (2004) adibidez, arreta Gödel kasuan jarri izana: Ezjakite eta Akatsaren argudioan "kasu arruntei buruzko intuizioek askoz zeregin garrantzitsuagoa daukate" (Devitt 2011b: 421).

7 Donnellanek adibide polit bat dauka erakusten duena zein erraza den kasu arruntak asmatzea. Haur bat lotatik esnatu berria da festa batean eta "Tom" izeneko pertsona bat aurkezten diote. "Gero haurrak zera esaten die gurasoei, 'Tom gizon atsegina da' (...) deskripzio gisa, edo ezagutzeko disposizio gisa haurrak daukan ezerk ez du balio pertsona bakar bat ohiko moduan bereizteko" (1972: 364). Haurra aurkeztu zioten pertsona hari buruz ari da, ordea.

8 Eta intuizio horiek baieztatu egin dira berriki erabilera-proba esperimentaletan; ikus Domaneschi et al. (2017), Devitt eta Porot (2018).
} 
$\mathrm{du}$ " $N$ "ren erreferentzia. Horko $R$ erlazio hori erreferentziaren aurkako teoria ez-deskriptibistatik (kate kausal-historikoaren iruditik, adibidez) hartua da. (2020: 90) ${ }^{9}$

Teoria "burutsua da, baina susmagarria" (Devitt eta Sterelny 1999: 61); hasteko, teoria kausal-historikoaren bizkarroia delako.

Teoriaren kontrako argudio bat da eskatzen duela hiztun konpetente orok lotu behar diola " $N$ "ri goiko "R-deskripzioa" eta, beraz, izatez, jakin egin behar duela " $N$ " erreferentearekin $R$ erlazioan dagoela, teoria kausal-historikoak zehaztutako erlazioa baita $R$. Kontuan har deskriptibismo kausalak ez duela eskatzen hiztunek teoria hori bera jakitea, " $N$ "k bere erreferentea erreferitzea horrelako loturen edo ezagutzaren araberakoa dela. Baina eskatu, eskatzen du hiztunek teoriaren oinarrian dagoen ezagutza izatea. Hori nahiko onargaitza da, teoriko kausalak beraiek ere ez bailirateke erreferentzia mugatzen duen $R$ erlazioa aurkitu dutela pentsatzeko bezain harroak! Deskriptibismo kausala ezjakite- eta akatsproblemak saihesteko diseinatu bazen ere, problema handi bat sortu du. ${ }^{10}$

Seguru asko Kripkek egingo zion objekzio hori bera deskriptibismo kausalari. Eta begi onez ikus dezake hauxe bera ere, teoriaren bihotz bizkarroiari erasotzen dion hau (Devitt eta Sterelny 1999: 61). Deskriptibismo kausalaren arabera, hiztunek " $N$ " ri R-deskripzioa lotzeak mugatzen du erreferentzia. Baina lotura horrek erredundantea izan behar du. " $N$ "ren erreferentea $R$-deskripzioak identifikatzen duen objektua dela baieztatzean, deskriptibista kausalak onartzen $\mathrm{du}$ " $N$ "k R erlazio bereizle bat duela erreferente horrekin. Orduan $R$ bera nahikoa da erreferentzia esplikatzeko. Hiztunak $R$-deskripzioa lotzea eskatzeak ez du zeregin teorikorik batere.

Ezjakite eta Akatsaren argudioen boterea eta eragin-eremua itzelak dira, eta aintzat behar beste hartu gabeak. Edozein terminoren edozein deskripzioteoriak egin behar dio aurre Ezjakite eta Akatsaren erronkari. Hori ez da esatea teoria horiek guztiek erronkan huts egiten dutela. Adibidez, "emaztegabe" klase sozialaren terminoaren deskripzio-teoria batek ez du hutsik egiten, beharbada; hiztun konpetente guztiek "emaztegabe"ri "ezkondu gabeko gizonezko heldu" lotzen diote, beharbada. Baina zer esan "ordenagailu"ren gisako "tresna"-klase terminoei buruz? Jendeak zuzen deskriba al dezake ordenagailu bat? Eta "tigre" eta "urre" moduko klase "natural"en terminoentzako deskripzio-teorien aurka Kripkek (116-43, 156-57) ematen dituen argudio ezagunek, Ezjakite eta Akats baino gehiago Nahi Gabeko Beharrezkotasunaren argudio direnek, erakusten dute teoria horiek huts egiten dutela erron-

\footnotetext{
9 Harvarden 1970ean Robert Nozicki entzun nion lehen aldiz deskriptibismo kausalaren berri, teoria kausala proposatzen zuen nire gradu mailako ikasle-hitzaldiari erantzunez. Kripkek ere $(88,38$. oin-oharra) Nozickengandik entzun zuen lehen aldiz teoria horren berri.

10 Objekzio honek ez du Jackson (2020) inpresionatu. Erantzun egin diot (2020: 19.2.5.1).
} 
kan. Kontuan har Putnamen (1975) "zumar"en adibide polita: itxuraz konpetente diren hiztun gehienek ezin dituzte zumarrak bakarki deskribatu edo ezin dute zuhaitz multzo batean zumarra bereizi.

Ezjakite eta Akatsak Wittgensteinek inspiratutako Paul Horwichen (1998) "esanahiaren erabilpen-teoria" ere harrapatzen du. Termino askoren hiztun konpetenteak maiz beren erreferenteei buruz ezjakin edo oker daudela erakusten duten argudio berberek erakusten dute termino horien erabilerak asko aldatzen direla hiztunen komunitatean. Horwichek argi deskribatzen du problema bere erabilpen-teoriarentzat: "hizkuntz komunitate bateko kideek normalean, hitz jakin baten bidez, justu gauza bera esan nahi dute, baita beren erabilerak desberdinak direnean ere" (85-86). Saiatu da problema konpontzen "eskuordetze" ari helduz (1998, 2005, 2020), baina, argudiatu dudanez, soluzio horrek huts egiten du. Izan ere, Ezjakite eta Akatsak esanahiaren erabilpen-teoriaren ideiaren beraren kontra jotzen du (2002, 2011a, 2020: 19.3.5).

Ezjakitea eta Akatsa erabili dut (1985: 225-27) Gareth Evansen (1982: 69-79) "Russellen Printzipioa"ren kontra ere, zeinaren arabera "batek objektu bati buruz pentsatzeko, jakin egin behar du[en] zein objektu den" (65); eta "mahaia"ren gisako deskripzio ez-osoak jorratzeko russelldar saiakeren kontra. Areago, Ezjakitea eta Akatsa kaltegarria da oso "semantika lexiko"aren belaze joriarentzat, nahiz eta oharkabean iraun duen han berrogeita hamar urtez. ${ }^{11}$ Azkenik, Ezjakite eta Akatsaren aurrean (eta beheko erreferentzia-mailegatzearen aurrean), garaia da alde batera uzteko oraindik ere horren ohikoa den suposizioa, adierazpen baten hiztun konpetenteek bere esanahia jakin behar dutela dioena.

\section{3. "Irudi" kausal-historikoa}

"Eskuordetzea", Horwichek eta beste hainbestek ulertzen duten eran, hizkuntzaren teoriari Kripkek egindako beste ekarpen itzelaren bertsio endekatua da: erreferentzia mailegatzearen bere teoria positiboarena. Nola liteke izenen, eta agian beste termino askoren, erreferentziei buruz horren ezjakin eta oker dagoen jendeak, hala ere, horiek erreferitzeko arrakastaz erabiltzea? Erantzunaren zati handi bat eskaini zuen Kripkek: jendeak "maileguan" hartzen ditu terminoen erreferentziak komunikazio-egoeretan; erreferentzia mugatzea kontu soziala da indibiduala baino gehiago. Eta mailegatzea epistemikoki gutxi eskatzen duen prozesu kausala da, erreferentea identifikatzeko inolako gaitasunik eskatzen ez duena. Ideia erradikal hau da erreferentziaren Kripkeren "irudi hobea"ren gakoa (94 [51-52]).

11 Hala, Ezjakitea eta Akatsa, Kripke, Donnellan eta Putnamekin batera, ez dira aipatu ere egiten Pustejovskiren (1995) lexikoaren azterketa zabalean. 
Bertsio endekatua, eskuordetzea, Kripkeren proposamenaren ohiko gaizki-ulertze batetik sortu zen. Kripkek baieztatzen du pertsona batek, izen bat maileguan hartzean, "izan behar du[ela] (...) ikasten duenean (...) erreferentzia berarekin erabiltzeko asmoa" (96 [53]). Hortaz, Kripke esaten ari da maileguan hartzen duenak mailegatzearen unean izan behar duela asmoa, izena mailegatzailearen erreferentzia berarekin erabiltzeko. ${ }^{12}$ Baieztapena eskuarki gaizki ulertzen da, maileguz hartzen duenak, gerora izena erabiltzen duenero, mailegatzailearen erreferentzia berarekin erabiltzeko asmoa izan behar balu bezala. Hala, John Searlek (1983: 234) Kripkeren baieztapena aipatzen du, baina segidan gaizki interpretatzen $\mathrm{du}$, honela:

... hiztun bakoitzak asmoa izan behar du izena ikasi zion pertsonak erreferitutako objektu berari erreferitzeko. Beraz, kate kausalean " $N$ "ren erabilera bakoitzari lotutako eduki Intentzional bat ematen digu horrek, hots, " $N$ " izena ikasi nion pertsonak erreferitutako objektua da. (235-36).

Searleren arabera, beraz, Kripkek eskatzen du hiztunak, izena erabiltzen duen unean, izan dezala asmo bat erreferentzia-mailegatzaileari zuzendua. ${ }^{13}$ Eta hori da normalki jendeak buruan duena hiztunak mailegatzaileari "eskuordetzea"z ari denean. Baina Kripkek ez du beharrezkotzat jotzen halako "atzerakako" asmorik erabileraren unean. Izan ere, halako baldintza bat nahiko arrotza zaie bere eztabaidari eta Strawsonen (1959) erreferentziamailegatzearen deskripzio-teoriaren eta berearen artean nabarmentzen duen aldeari. Strawsonen teoriak huts egiten du, hain zuzen ere, izenen erabiltzaile konpetenteengan beharrezkotzat jotzen duelako erreferentzia-mailegatzaileen ezagutza (92-93). ${ }^{14}$

Erreferentzia maileguz bereganatu duen izen baten erabilera arrakastatsua izenari lotutako gaitasun batek sortua da, eta gaitasun hori, izatez, mailegatzearen bidez errotzen da izenaren jabearengan: gaitasun efikazak historia

\footnotetext{
12 Nik (1974, 1981a, 2015) mailegatze horren azalpen gordinagoa, kausalagoa eta ez horren intelektualizatutakoa bultzatzen dut.

13 Gaizki-ulertze honen ezagutzen dudan lehen adibidea Michael Dummettena (1973: 147-51) da.

14 Keith Donnellanen proposamena Kripkerenaren antzekoa da (Bianchik eta Bonaninik (2014) esanak esan) eta ez du atzerakako asmorik ere beharrezkotzat jotzen. "Teoriagile kausalen" batek beharrezkotzat jo al zuen inoiz? (1) Agian Putnamek joko zuen "lan linguistikoaren banaketa"ren eztabaidan. Ideia aurkeztean (1973: 705) ez dirudi baldintzarik iradokitzen duenik, baina geroko eztabaida hala har daiteke: "nire denotazioa izan daiteke, onarpen orokorrez, nigandik espazioan eta denboran ere urrun dauden pertsonek, baina kooperazio-erlazioz niri lotuak diren pertsonek esleitutako denotazioa". Uste du horrela "bertan behera uzten ari naiz[ela] nire hitzen denotazioen autoritatea izateko eskubidea" (1975: 274); "oso maiz hiztunek adituei eskuordetzen diete erreferentzia mugatzea" (1978: 114). (2) Kaplanek beharrezkotzat jo zuela ematen du. Izen propio baten erabilpenaz (ez-kreatiboaz) esaten du lotua dagoela "hitza ikasi zenion pertsonak emandako esanahiarekin erabiltzeko asmoari". Gero esaten duenean "batek izen propioa asmo [horrekin] erabiltzen duenean" (1989a: 559), horrek inplikatzen du asmo horrek erabilera bakoitzari laguntzen diola eta ez dagoela presente ikasteko unean soilik.
} 
kausal egokia izan behar du. Hori da behar den bakarra. Thomas Blackburnek (1988: 184) dioenaren aurka, ez dugu zertan beharrezkotzat jo izena maileguan hartzen duenak historia hori onartu edo aitortzea. Eta Adèle Mercierrek (1999) dioenaren aurka, ez dugu zertan beharrezkotzat jo izena maileguan hartu duenak izenaz egin duen erabilpen arrakastatsuari eskuordetzeko asmo batek lagundu izana. ${ }^{15}$ Hiztunak gaitasun bat ustiatzen du, izatez mailegatua dena, baina hiztunak ez du zertan mailegatzaileari eskuordetu. Izan ere, hiztunak ez du zertan jakin mailegatzailea zein den edo izena maileguan hartu duenik ere. ${ }^{16}$

Eta noraino iristen da erreferentzia-mailegua? Kripkeren arabera, ez da izenen ezaugarria soilik; klase "natural"en terminoena ere bada. Eta Putnam urrunago joan zen "lan linguistikoaren banaketa" rekin $(1973,1975)$. Raatikainenek uste du "termino mota oro har daiteke[ela] maileguan", baita "emaztegabe" ere (2020: 85-86). Ez dakit. Har gogoan "tresna"-klase terminoak. Egiantzekoa dirudi "balandro" edo "daga"ren gisako terminoak maileguan har daitezkeela. Baina, hala bada, izen propioen modura, maileguaren teoria "kausal-puru" baten araberakoak lirateke? Sterelnyk eta biok esan genuen beharbada ezetz (1999: 93-101): nahiz eta "balandro" "masta bakarra eta nagusia eta fokea daraman itsasontzi"rekin lotu gabe zuregana dezakezun, beharbada ezin duzu zureganatu "itsasontzi" rekin lotu gabe. Eta zer esan "itsasontzi" edo "arma" "tresna"-termino oinarrizkoagoei buruz? Benetan egiantzekoa al da maileguan har daitezkeela? Galdera horiekin daukagun lehen problema da ez daukagula intuizio sendorik. Bigarren problema da hemen, erreferentziaren teorian beste inon baino gehiago, intuizioez haragoko sostengua behar dugula. Erabileratik datorren ebidentzia behar dugu (2011b, 2012a,b). Zer ote dio Kripkek horri buruz? ${ }^{17}$

Erreferentzia-maileguaren ondorioz, guztiok izan dezakegu arrakasta Aristoteles bere izenarekin designatzean, Aristotelesengan izenaren erreferentzia ezarri zuten jatorrizko erabiltzaileengana atzera garamatzan erreferentzia-maileguen kate bati esker. Baina nola egin zuten hori jatorrizko erabiltzaileek? Nola ezarri zuten erreferentzia lehenengoz? Kripkek ez zuen horri buruzko gauza handirik esan 1967ko klaseetan, baina nolabaiteko deskripzio-teoriaren bat begi onez ikusiko lukeela dirudi: izen-emate batean, pertsona batek objektu batean ezartzen du erreferentzia, objektuaren deskripzio baten bidez. Howard

\footnotetext{
15 Nondik dator "eskuordetzea"ri buruzko jardun hau? Testuinguru honetan, halako lehen jarduna Gareth Evansena (1973: 205-6) dela dirudi, teoria kausala kritikatzen eta berea aurkezten ari dela.

16 Ikus Devitt (2015: 116-8) ideia honen duela gutxiko garapen baterako.

17 Erreferentziaren teoriak filosofoen erreferentzia-intuizioetan oinarritzeko praktika gogor kritikatu dute "filosofo esperimentalek" (Machery et al. 2004). Horrek eztabaida bizia piztu zuen: Ludwig (2007); Martí (2009, 2012); Machery et al. (2009); Weinberg et al. (2010); Devitt (2011b; 2012a,b); Sytsma \& Livengood (2011); Ichikawa et al. (2012); Machery \& Stich (2012); Machery (2012a,b); Machery et al. (2013) besteak beste.
} 
Wettsteinek (2012: 115) uste du hori zela Kripkeren "paradigma". ${ }^{18}$ Liburuan Kripkek hitz egiten du "erreferentzia deskripzioz edo ostentsioz" ezartzeaz (97 [53-54]), baina ez du ostentsioaren azalpenik eskaintzen. Utzi alde batera "Jack tripa-ateratzailea"ren gisako "izen deskriptiboak"19 eta hartu aintzat "Aristoteles"en gisako paradigma-izenak. Nire ikuskera da paradigma-izen baten erreferentzia objektu batean ezartzen dela, zuzenean ala zeharka, pertsona baten eta objektuaren arteko lotura kausal baten bidez, pertsona horren hautemate-fokoa denean. ${ }^{20}$ Hori da nik "oinarritzea" esaten diodana, eta zentrala zen erreferentzia naturalizatzeko nire saioarentzat (1974, 1981a, 2015). ${ }^{21}$ Erreferentzia ezartzearen ikuskera honen arabera, hortaz, jatorrizko erabiltzaileek gaitasuna dute "Aristoteles"en bidez Aristoteles designatzeko, harekin daukaten lotura kausalari esker, eta gero oinordetzan jaso dugu gaitasun hori, erreferentziamaileguz. Ez genuke pentsatu behar Kripkek erreferentzia ezartzearen ikuskera hau onartuko lukeenik.

\section{Deskripzio-teoriak eta Galdutako Zurruntasuna}

Erreferentziaren teoriaren iraultzan, mugarri nabarmenen arteko beste bat izan zen termino batzuk "zurrunak" direla dioen Kripkeren baieztapena. Designatzaile zurruna definitzen du objektua existitzen den mundu posible guztietan objektu bera designatzen duen haren gisan. Designatzaile batek hori egiten ez badu, ez-zurruna da (48). Kripkek argudiatzen du izen propioak zurrunak direla, baina deskripzioak, deskripzio-teorien arabera izenaren esanahia adieraziko luketen horien modukoak, ez. Adibidez, "Aristoteles" zurruna da, baina Fregek bere esanahi gisa iradokitzen duena, "Platonen ikaslea eta Alexandro Handiaren irakaslea", ez. Hortaz, izena ez da deskripzio baten sinonimoa eta deskripzio-teoriak oker daude. Hori da Galdutako Zurruntasunaren argudioa. Hainbat gauza dauzkat esateko argudio horri buruz.

(I) Deskripzio-Teoriak Salbatu. Kripkek dioen bezala, argudioak deskripzioteorien aurka egiten du, horiek, ohikoa denez, izenak esan nahi duenari buruzko teoriatzat hartzen badira, baina ez izenaren erreferentzia mugatzen duenari bu-

18 Eta hori da Hilary Putnamen ikuskera: "erreferentziaren teoria externalistetan ere deskripzioek zeregin gakoa daukate: izen-emaile jatorrizkoak edo jatorrizkoek deskripzio definituen bidez identifikatzen dute, edo identifikatzeko gaitasuna dute, hizpide duten hori" (2001: 496-7).

19 Horiek beste era batera jorratu behar dira, nire ustez (1974: 195-96; 1981a: 40-41; 2015: 124-25, 135-38).

${ }^{20}$ Bistan da bestelako istorio bat behar dela zenbakien moduko objektu abstraktuen izenentzat.

21 Normalean izenek askotariko oinarritzea daukate beren jabeetan (1974: 198). Horrek bidea ematen du teoria kausal-historiko batek erreferentzia-aldaketa esplikatzeko, Gareth Evansen "Madagaskar" adibide famatuan bezala. Labur esanda, izen baten erreferentzia $x$ tik $y$ ra aldatzen da bere oinarritzeen patroia $x$ n egotetik $y$ n egotera aldatzen denean (1981a: 138-52; 2015: 121-24). Hala ere, Evansen ideia okerrak, zeinaren arabera erreferentzia-aldaketen kasuak "Izenen Teoria Kausalaren aurka erabakigarriak baitira", bizirik dirau (Searle 1983; Sullivan 2010; Dickie 2011). 
ruzko teoriatzat hartzen badira. Azken interpretazioak problema asko ditu, hala ere (Devitt eta Sterelny 1999: 53). Deskripzio-teoriak salbatzeko modu hobea da, Kripkeren puntua egokitzeko, teoria horiek aldatzea: izen baten esanahia beste deskripzio mota batek ematen du, zurrundutako batek. Hala, "Aristoteles"en esanahi gisa Fregek iradokitakoaren ordez, aldatutako teoriak esaten du honako deskripzio zurrun honek ematen duela esanahia: "Platonen ikaslea eta Alexandro Handiaren irakaslea izan zen mundu errealeko pertsona".

Erantzun eraginkorra da hau Galdutako Zurruntasunaren argudioarentzat. Ez dago halako erantzunik Ezjakite eta Akatsaren argudioarentzat.

(II) Intuizio Metafisikoak. Baten batek tentazioa izan dezake pentsatzeko deskripzio-teorien Kripkeren errefutazioak erreferentzia-intuizioetan daukala euskarria. ${ }^{22}$ Eta hori nahiko egia da Ezjakite eta Akatsari dagokionez, baina ez da egia Nahi Gabeko Beharrezkotasunari eta Galdutako Zurruntasunari dagokienez: argudio horiek modalitateari eta esentziari buruzko intuizio metafisikoetan daukate euskarria; situazio kontrafaktiko batean " $N$ "k erreferitzen duenari buruzko edozein intuizio situazio horretan $N$ zein objektu den edo ez delako auziaz ari diren intuizioetatik eratortzen da. Bistakoa da hori Nahi Gabeko Beharrezkotasunarekin, ${ }^{23}$ baina beharbada ez da hala Galdutako Zurruntasunarekin. Argudio horren lau bertsio bereiz ditzakegu:

(A) Kripkek esaten du "nahiz eta AEBetako 1970eko presidentea ez den bat izan zitekeen AEBetako 1970eko presidentea (...) Nixon ez den beste inor ezin zitekeen izan Nixon" (48). Hori baieztapen modala da, honako ikuskera honetatik datorrena: AEBetako 1970eko presidentea izatea ez zaio esentziala Nixon izateari, baina Nixon izatea bai. Intuizio modal horretan oinarrituta, Kripkek esaten du "Nixon"ek gainditzen duela zurruntasunerako "test intuitiboa", baina "AEBetako 1970eko presidentea"k huts egiten duela (48).

(B) Kripkek esaten du Hesperus Phosphorus denez, beharrezkoa dela Hesperus Phosphorus izatea. Baina deskripzioekin ordezkatzeak —esate baterako, "arratsean ikusitako planeta" "Hesperus"en ordez, eta "goizean ikusitako planeta" "Phosphorus"en ordez- egia hori faltsu bihurtzen du. Izenak, deskripzioak ez bezala, zurrunak dira (3-5, 98-102 [54-58]). Identitateari buruzko intuizio modaletan oinarritzen da hori.

(C) Honako hauen gisako perpaus modalek eragin-anbiguotasuna daukate:

(a) Gerta zitekeena zen antzinako azken filosofo handia ez izatea filosofo.

(b) Gerta zitekeena zen Aristoteles ez izatea filosofo.

22 Ikus, esaterako, Machery et al. (2004).

23 Bereziki da bistakoa, klase naturalen terminoen eztabaidan (116-43, 156-57). 
"Antzinako azken filosofo handia"ren eragina (a)n eta "Aristoteles"ena (b)n zabala izan daiteke, edo estua. Baina Kripkek dio (b)ren bi irakurketak baliokideak direla baina (a)renak ez. Baliokidetza hori "Aristoteles"en zurruntasunaren marka da $(10-12,62)$. Argudioak honako ikuskera honetan dauka euskarria: filosofo izatea ez da Aristotelesen propietate esentziala.

(D) Azkenik, kontuan hartu Galdutako Zurruntasunaren argudioaren bertsiorik garrantzitsuena iruditzen zaidana. ${ }^{24}$ Lehen aldiz Naming and Necessityren Hitzaurrean agertu zen. Honako honi buruz ari dela,

(1) Aristoteles txakurzalea zen,

Krikpek zera dio,

Seguru asko mundu guztia bat dator: badago gizon jakin bat — guk "Aristoteles" esaten diogun filosofoa- zeina, izan ere, (1) egiazkoa baita baldin eta bakarrik baldin bera txakurzalea bazen. Designazio zurrunaren tesia da soilik (...) paradigma bera aplikatzen zaiela (1)en egibaldintzei situazio kontrafaktikoak deskribatzen dituenean. Alegia, (1)ek egiazki deskribatzen du situazio kontrafaktiko bat baldin eta bakarrik baldin, situazioa gertatuz gero, lehen aipatutako gizon hori bera txakurzalea balitz. (6)

Pentsa situazio kontrafaktikoa jarraian azaldutakoa dela. Egiazki guk "Aristoteles" esaten diogun filosofo famatua izatera heldu zen pertsona nerabea zela hil zen, batere filosofiarik ikasi baino lehen. Zirkunstantzia horietan antzinako azken filosofo handia beste norbait izango zen; esate baterako, Platon. Kripkeren intuizioa da Aristoteles txakurzalea ote zen, beraz, (1) egiazkoa ote den, nerabe hura txakurzale izatearen mendekoa dela, ez Platon txakurzale izatearen mendekoa. Hortaz, situazio kontrafaktiko horretan, (1)eko "Aristoteles"ek nerabea erreferitzen du, gure Aristoteles erreala dena, eta ez Plato. Hortaz, "Aristoteles" zurruna da. Kripkeren intuizioa Aristotelesi esentziala zaionari buruzkoa da; nerabe hura izatea esentziala zaio, antzinako filosoforik handiena izatea ez. ${ }^{25}$

Beraz, indibiduo bati esentziala zaionari eta ez zaionari buruz Kripkek duen ikuskera dago Galdutako Zurruntasunaren argudioaren atzean. 8. atalean gehiago izango dugu esateko esentzialismo indibidualari buruz.

${ }^{24}$ Aurreko lanetan (A)tik (D)ra eztabaidatzean, oker onartu nuen (D) bertsio honek "erreferentziari buruzko intuizioetan euskarria badu"ela (2011b: 422).

25 Bat nator "Aristoteles"en gisako paradigma-izenak zurrunak direlako Kripkeren intuizioarekin. Zurruntasun hori esplika daiteke bere erreferentzien teoria kausal baten bidez (2005: 145). Baina zer esan "Jack tripa-ateratzailea"ren gisako deskripzio-izen ez-paradigmatikoei buruz, zeinen halako esplikaziorik ez baita posible? Nathan Salmonek uste du "aingeruak eta filosofo zentzudun guztiak limurtu ditu Kripkek" horiek ere zurrunak direla (2020). Nik zalantza egiten dut horien zurruntasunez (2015: 136-37; 2020: 19.3.2), nahiz eta puntako aingeru baten izena daramadan. 
(III) Klase Naturalen Terminoak eta Zurruntasunaren Lana. Kripkek dio "klase natural"en hainbat termino orokor izen propioen antzekoak direla. Argi asko uste du antza duten moduetako bat zurrunak izatean datzala (127-36). Gogoan dauzkan terminoak honako hauek dira:

hainbat espezie-izen, "katu", "tigre", "urre puska"ren gisako izen zenbakarriak izan edo "urre", "ur", "burdin pirita"ren gisako masa-terminoak izan (...) "bero", "argi", "hots", "tximista"ren gisako fenomeno naturalentzako hainbat termino, eta, seguru asko, behar bezala jorratuta, (...) dagozkion adjektiboak: "bero", "ozen", "gorri". (134)

Kripkek ez du eskaintzen termino horientzako designazio zurrunaren definizio berririk eta, hortaz, batek pentsa dezake zaharra aplikatu beharko litzaiekeela. Baina hori nola litekeen jakin nahi dugu. "Aristoteles" eta "antzinako azken filosofo handia" entitate zehatz jakin bat designatzen duten termino singularrak dira eta, hortaz, erraza da ikustea zurrunak ala ez-zurrunak izan daitezkeela. Hala ere, hemen Kripkek gogoan dauzkan terminoak ez dira singularrak. Zer designa dezakete zurrunki? Hainbat filosofok proposatu du termino hauek nolabaiteko objektu abstraktuak designa ditzaketela zurrunki, klaseak, propietateak edo atributuak. ${ }^{26}$ Ikuskera horiek kritikatu egin ditut nik (2005), beste hainbatek bezala. ${ }^{27}$ Baina ez nator bat kritika horien gai komun bati dagokionez, Stephen Schwartzek (1977, 1980, 2002, 2020) indartsu azpimarratu duen gaiari dagokionez. Schwartzen arabera, zurruntasunaren ideia onargarri batek klase naturalen terminoak eta "arkatz", "ehiztari" eta "emaztegabe"ren gisako ez-naturalekoak bereizteko lan teorikoa egin behar du. Objektu abstraktuen ikuskerek huts egingo dute lanbide horretan.

Oso ados nago Schwartzekin dioenean zurruntasun-nozio batek lan teorikoa egin behar duela, baina hori ez da egin behar duen lana. Kripkek zurruntasunari eman zion lehen lana, ikusi berri dugunez eta argudiatu izan dudanez (2005), esanahiaren deskripzio-teorien aurkako Galdutako Zurruntasunaren argudioetan azaltzea zen. Hori da zurruntasun-nozio onargarri batek egin behar duen lana. Eta objektu abstraktuen ikuskerek duten problema bat da huts egiten dutela hori egitean.

Egia da klase-termino zurrunen Kripkeren adibide faboritoak klase naturalen terminoak direla (edo hori argudia daiteke). Hala ere, Kripkek ez du baieztatzen klase naturalen termino guztiak zurrunak direnik, ezta ez-naturaleko guztiak ez-zurrunak direnik ere. Izan ere, berak uste du "seguru asko,

\footnotetext{
26 Mondadori (1978), Donnellan (1983), Boer (1985), LaPorte (2000). Proposamen horrentzako euskarri bat badago Kripkerengan: horitasun "propietate fisikoaz" dio zurrunki designatzen duela "hori", zeinak "alderdi honetan klase naturalen terminoen antza baitu" (128. oh.).

27 E.g. Cook (1989) eta Macbeth (1995).
} 
behar bezala jorratuta, (...) "bero", "ozen", "gorri"” zurrunen artean daudela; ikus, baita ere, horitasunari buruzko eztabaida (128. oh.). Areago, galdetu beharko genuke zurruntasunak nola izan lezakeen klase naturalen terminoak bereizteko zeregin teorikoki interesgarririk. Tribiala da termino bat klase naturalen terminoa dela baldin eta bakarrik baldin (bba) klase natural bat erreferitzen badu. Eta klaseak bereizten baditugu, terminoak bereizten ditugu; eta alderantziz. Eta klaseak bereizten hasi beharko genuke, horrela, terminoak bereizteko: "aurrena metafisika jarri" beharko genuke, nire gustuko esapidea erabiliz (2010). Izan ere, dezenteko nabarmenkeria da pentsatzea kontrako norabidean joan gaitezkeela, klase naturalak bereiziz klase naturalen terminoen tesi semantiko baten bidez. Ziur nago Kripke bat etorriko litzatekeela.

Klase naturalen terminoentzako zurruntasunaren nozio teorikoki erabilgarri batek Galdutako Zurruntasunaren argudioan azaldu beharra dauka. Argudiatu dudanez, honako nozio honek, aplikazio zurrunak, ederki beteko du lan hori:

\begin{abstract}
" $F$ " termino orokor bat aplikatzaile zurruna da bba halakoa baita non, mundu posibleren batean objektu bati aplikatzen bazaio, orduan objektu horri aplikatzen bazaio, objektua existitzen den mundu posible orotan. Eta antzera masa-termino batentzat. (2005: 146).
\end{abstract}

Schwartz (2002, 2020) ez dator bat. Erantzun diot (2020: 19.3.3).

\title{
5. Erreferentzia zuzena
}

Kripkek erakutsi zuen izen propio baten esanahia ezin zela deskriptiboa izan, baina orduan zer zen? Kripke oso gaizki ulertua izan da, "erreferentzia zuzenak" emandako erantzunaren alde egin balu bezala: izen baten esanahia ("balio semantikoa", "eduki semantikoa", eta abar) bere jabea da, besterik ez. Baina, izan ere, Kripkek ez du aukerarik egiten Hitzaurrean (20-21) eta eutsi egin die hesitik irtenarazteko saio guztiei.

Erreferentzia zuzena, nik ulertzen dudan eran,28 teoria "milliarra"ren berpizte bat besterik ez da. Eta, hortaz, problema ezagunei, eta itxuraz sekulakoei, egin behar die aurre, aspaldi Frege eta Russell millianismoa bazterrean utzi eta deskripzio-teoriak besarkatzera eraman zituztenei (identitate -baiezpenak, existentzia-baiezpen negatiboak, eta abar). Problema horiexek direla-eta, urte askoan, ez nuen gogoan hartu erreferentzia zuzena izen baten esanahiaren teoriarako hautagai gisa ere. Baina, orduan, 80ko hamarkadaren erdialdera, erreferentzia zuzenaren ospeak ezinezkoa egin zuen aintzat ez

28 "Erreferentzia zuzena" beste era batzuetara ulertzen da maiz. "Erreferentzia zuzena"ren teoriak eta bere historiak laburtu ditut beste nonbait (1989: 206-12; ikus, baita ere, 1996: 170. oh.). 
hartzea. ${ }^{29}$ Izan ere, garai hartarako, jasotako ikuskera zen, baita kontrairaultzaileen artean ere, izen baten erreferentziaren Kripkeren teoria ez-deskriptibistaren ondorioa zela erreferentzia zuzena. ${ }^{30}$ Horren historia bitxia da.

Dena dela, kontatu baino lehen, honako galdera hau hartu beharko genuke gogoan: zergatik pentsatu zuen jendeak, lagunek nahiz etsaiek, iraultzak erreferentzia zuzena inplikatzen duela? Erantzuna argia da: alternatibarik ez zegoela pentsatu zuen jendeak. Baina bada bat. Millianismoarentzat itxuraz sekulakoak ziren problemek arrazoi on bat eman zioten Fregeri izen batek esanahi bat baduela baieztatzeko, bere jabeari erreferentzia egiteko modua dena. Modu hori jabearen deskripzio bat dela proposatu zuen. Hori ez dela egokia izan erakutsi du Kripkek. Eta, hala ere, izen batek badu erreferitzeko moduren bat, bistan da. Kripkeren "irudi hobeak" ematen du giltza: izen batek nola-halako modu kausal-historikoa dauka. Hortaz, hori da izenaren esanahia. Horixe proposatu nuen hasieratik (1974: 204). ${ }^{31}$ Askoz beranduago ohartu nintzen ideia hori, niretzat hain naturala, ezen interesik gabea ere iruditzen baitzitzaidan -lehen aurkezpena zalaparta handirik gabeko paragrafo labur batean izan zen-, askori harrigarri iruditu zitzaiela, eta hala deitu nion gero: "Esanahiari buruzko Ideia Harrigarria ["A Shocking Idea about Meaning"] (2001). Eta uste dut horrexegatik ez zela alternatiba hori aintzat hartu. ${ }^{32}$ Harrigarria izan baliteke ere, izenen esanahiaren arazoa konpontzen du eta ez dirudi ezer daukanik bere aurka, pentsatzeko modu tradizionaletarako atxikimendu erratu batez aparte.

Orain erreferentzia zuzenaren historia bitxia. Erreferentzia zuzena izatez iraultza kripkearraren parte zela zioen baiezpen goiztiar bat Brian Loarrena da, iraultzarekin kritikoa zen artikulu batean (1976: 355). Loar urrunago joan zen, esanez erreferentzia zuzena zela "erreferitzearen teoria kausalen interes filosofiko nagusia" (368). Baina, erantzun batean esan nuen bezala (1980: 272-73), erreferentzia zuzenik ez da topatzen Loarrek aipatzen dituen artikulu bakarretan, Kripkeren (1972) eta Donnellanen (1972) artikuluetan. Eta ohartarazi beharko genuke Schwartzek, gutxi gorabehera Loarren garai berean idatziz, "teoria berria" esaten dionaren "ezaugarri nagusiak" zerrendatzen dituela erreferentzia zuzena aipatu ere egin gabe (1977: 20-34). Loarren baieztapenak eraman ninduen esatera erreferentzia zuzena "ebidentziarik gabe inori bizkarrera-

${ }^{29}$ Ikus Barwise eta Perry (1983: 165); Almog (1984, 1985); Salmon (1986); Soames (1985, 1987); Wettstein (1986). Kritiketarako ikus nire (1989, 1996, 2012c). Duela gutxiko truke baterako, ikus Braun (2020) eta nire (2020: 19.3.1). Nire ustez, erreferentzia zuzena teorikoki motibatu gabea da.

30 Ikus, adibidez, McGinn (1982: 244); Baker (1982: 227); Lycan (1985); Block (1987: 660, 665); Lepore eta Loewer (1987: 60); Wagner (1986: 452).

31 Nire (2015: 130-33), duela gutxiko lanketa da.

32 Alternatiba honen aurrean erreferentzia zuzenaren bi "gizon gogorrek" hartu zuten jarrera interesgarria da: Salmonek honela deskribatzen du "gaizki sortua, ez bada erabat desesperatua (...) basatiki bitxia (...) nahasketa bat, kategoria akats baten parekoa" (1986: 70-71); Soamesek (2002) existituko ez balitz bezala jokatzen du. 
tzeko sineskaitzegia" zela (1980: 273). Iraultzaren beste kritiko batzuk, Stephen Schiffer (1979) eta Felicia Ackerman (1979), azkar batu zitzaizkion Loarri Kripkeri erreferentzia zuzena oker bizkarreratzean. ${ }^{33}$ Baina oinarri askoz sendoagoa daukate ikuskera Donnellan (1974)n aurkitzerakoan. ${ }^{34}$ Horrez gain, Schiferrek baieztatzen du David Kaplanen "Dthat" (1978) famatuak "argi inplikatzen du"ela ikuskera (1979: 73, 5. oh.). Ez dut halako inplikazio argirik ikusten "Dthat"en (baina ikus behean gehiago Kaplani buruz). Ba al zen inor, agian Donnellan alde batera utzita, 70eko hamarkada inguruko urte haietan erreferentzia zuzena besarkatu zuenik iraultzak bultzatuta? ${ }^{35}$ Aurkitu ahal izan dudan argitalpen bakarra Michael Tyerena (1978) da. Pixka bat geroago, badago bat Tom McKayrena (1981). Biak ala biak, kritikoen antzera, oker daude ikuskera Kripkeri bizkarreratzean (Tye 1978: 220; McKay 1981: 301. oh.). ${ }^{36}$ Eta McKayk baieztatzen du: ikuskera "arin bihurtu da topiko bat" (287). Horrela, 70eko hamarkadaren bukaerarako erreferentzia zuzena benetan ondo asko zebilen airean, nahiz eta zehazki nondik zetorren modu gehienbat erratuan ikusi. ${ }^{37}$

Baina zer esan Kaplani buruz? Istorio zoragarria da hori. Nahiz eta izenen erreferentzia zuzenaren teoria ez egon argi "Dthat"en, egon badago "Demonstratives" (1989a) artikulu entzutetsuan, argitaratu baino askoz lehenagotik 70eko hamarkadan asko zabaldu zen horretan. Artikulu horrek sartu zuen "erreferentzia zuzena" terminoa, baina batez ere indexiko eta erakusleen eztabaidan erabili zuen. "Arrapaladan idatzitako atalean" (558) soilik egiten du bere, behin-behinekoz nolabait, izenen erreferentzia zuzenaren teoria (562). ${ }^{38}$ Eta, azken ohar batean, Kaplanek laburki nirearen antzeko ikuskera baten aukera zabaltzen du (563. oh.). Ikuskera hori gehiago arakatzen du bere "Afterthoughts"en, nahiz eta bere jarreratzat erreferentzia zuzena jotzen den (1989b: 574-77, 598-99). Hala ere, duela gutxi, eta harrigarriki, Kaplanek (2012) ia nire ikuskera bera proposatu du, eta ia nire arrazoi beragatik, itxuraz jakin gabe ikuskera berrogei urtean hor ibilia dela ${ }^{39}$ eta normalki harrigarritzat jotzen dela.

33 Schifferrek baieztatu egiten du, argudiatu gabe, "zaila d[ela], ez bada ezinezkoa, ikustea [Kripkek] nola bazter zezakeen" erreferentzia zuzena (1979: 63). Ackermanek bi pasarte aipatzen ditu Kripkeri bizkarreratzen dionaren euskarri. Eta onartzen du ez dela Donnellani bizkarreratzea "bezain argia" (1979: 68, 6. oh.). Aipuak ez dira konbentzigarriak.

34 Zalantza egin izan dut lehenago (1989: 209) erreferentzia zuzena Donnellan (1974)n aurki ote zitekeen, baina, Andrea Bianchiri esker, orain uste dut agian oker nagoela horri buruz. Geroko lan batean Donnellanek besarkatu egiten du egiaz erreferentzia zuzena (1989: 275-76).

35 Ruth Barcan Marcusek (1961) iraultza baino lehen besarkatu zuen ikuskera.

36 Bizkarreratze okerrak bere horretan segitzen du gaur-gaurkoz: "Baina Kripkek bide luzea egiten du Millekin batera. Katean beherako erabiltzailearentzat, izena milliarra da erabat —ez deskripziorik edo aurkezpen-modurik, ezta erreferentzia ezartzeko zereginean ere" (Wettstein 2012: 117).

37 Eskerrak Nathan Salmoni paragrafo honekin emandako laguntza eskolatuagatik.

38 Horretara bultzatu zuen argudioa eztabaidatu dut nik (1989: 213-15).

39 Nire proposamenaz gain, Panu Raatikainenek ohartarazi dit badela ohar bat non Kripkek ideia horren moduko bat aipatzen duen: "Hartry Fieldek proposatu du, Fregeren teoriaren helburu 


\section{Klase biologikoaren esentzialismoa}

Kripkek argudiatzen du klase "natural" batzuen izaera edo esentzia —tigreena eta katuena moduko klase biologikoena edo urrearena eta urarena moduko klase kimikoena- ez dagoela klase horietako kideen "kanpoko itxurek" osatua, ezta kide horiek identifikatzeko erabiltzen ditugun propietateek ere; esate baterako, tigreak ez dira esentzialki lauhankako felino haragijale handiak eta abar, Oxford Ingeles Hiztegiak deskribatzen duen bezala. Ikuskera metafisiko hori da Kripkeren euskarri nagusia, klase "natural"en termino baten erreferentzia kanpoko itxura horien deskripzioak mugatzen duela dioen deskripzio-teoria arbuiatzeko. Zein da orduan halako klase baten esentzia? Kripkeren arabera, azpian dagoen "barne-egitura" jakin bat da (neurri batean behintzat)" (119-21). Hala, urrearen "egitura atomikoa" ez duen ezer "ez litzateke urre izango" (124).

Atal honetan klase biologikoak hartuko ditut gogoan, klase kimikoak hurrengoan.

Zaila izango litzateke puztea biologoek eta, bereziki, biologiaren filosofoek izan dioten destaina Kripkek tigre, katu eta, oro har, espezieei buruz duen ikuskerari. "Esentzialismo aristoteliarra"ren usaina hartzen diote eta uste dute darwinismoarekin bateraezina den biologiari buruzko ikuskera desinformatu inozo bat erakusten duela. Horrela, Michael Rusek "Aristotelesen eskuinean nonbait" kokatzen ditu Kripke, eta antzeko ikuskera esentzialistak dauzkaten Putnam eta Wiggins, eta haiei buruz esaten du "mundu organikoari buruzko ezjakintasun ia harroa" erakusten dutela (1987: 358. oh.). John Duprék dio Putnamen eta Kripkeren ikuskerak urrundu egiten direla halabeharrez "biologiako benetako gertaera eta teoria batzuetatik" (1981: 66). Adostasunez hartutako espezieei buruzko ikuskera ez dator bat inondik ere Kripkeren esentzialismo intrintsekoarekin. Samir Okashak ondo harrapatzen du adostasun hori:

Biologiaren filosofo ia guztiek bat egiten dute (...) besterik gabe ez dela egia biologo aktiboek espezie-kidetzat hartzen dituzten organismo-taldeek beste espezieetatik bereizten dituzten ezaugarri morfologiko, fisiologiko edo genetiko komunik partekatzen dutela. (2002: 196)

Gai honi dagokionez, Sarah-Jane Leslieren arabera, "biologiaren filosofoen artean (eta biologoen artean) bada adostasun gradu bat, filosofian, oro har, ia aurrekaririk gabea dena" (2013: 132).

batzuetarako, erreferentzia mugatzen duen kateak ordezkatu beharko lukeela haren zentzu-nozioa" (1972: 346, 22. oh.; oharra ez da berriz azaltzen 1980ko liburuan). (Kripkeren 1967ko klaseetan zegoen Field. Hurrengo hilabeteetan hainbat aldiz hitz egin genuen klaseek planteatutako auziez. Izen baten esanahia erreferitzeko modu kausal baten gisa hartzeko ideia seguru atera zela eztabaida haietan). 
Biologiaren filosofoek uste dute, hortaz, tigreena moduko espezie baten izaera edo esentzia ez dela zeozer intrintsekoa. Zer uste dute orduan badela? Uste dute esentzia erlaziozkoa dela: organismo batek, espezie bateko kide izateko, historia jakin bat izan behar duela. Kim Sterelnyk eta Paul Griffithsek bere Sex and Death testuliburuan dioten bezala, "adostasunetik gertu dago espezieak bere historiek identifikatzen dituztela pentsatzea" (1999: 8).

Baliteke, hala ere, Kripke ados egotea honetan: badagoela espezie baten esentziaren osagai historiko bat intrintseko batez gain. Kontuan har pasarte hau, bestela:

Iraganeko esperientziak erakutsi du normalean [tigreak] moduko gauzek, elkarrekin bizi izanda, itxura berdintsua edukita, batzuek besteak estaltzen dituztela, klase bat osatzen dutela. Batak bestearekin zerikusia izan arren, uste baino gutxiago daukaten bi tigre klase baldin badaude, orduan familia biologiko handiagoa osatzen dute, beharbada. Zerikusirik batere ez badaukate, orduan, egiazki bi tigre klase daude. Hau guztia historiaren mende eta egiaz aurkitzen dugunaren mende dago. (121)

Nolanahi ere, Kripkeren baieztapenak, esentziaren barru-osagai egiturazko intrintseko bat dagoela dioenak, adostasunaren aurka egiten du.

Biologiaren filosofoek uste dute Kripkeren esentzialismo intrintsekoa, gertaera biologikoen ezjakintasuna erakusten duten "besaulki"ko intuizioetan oinarritua, oker dagoela besterik gabe. Horren kontra, nik argudiatu dut, izatez, Kripkeren intuizioak zuzenak direla eta euskarria dutela gertaera biologikoetan. Lehen argudioa "Resurrecting Biological Essentialism"en (2008) zegoen; argudiatu nuen espezieek (eta beste taxon batzuek) "esentziak dauzkate[la], oinarrizko propietate intrintsekoak direnak, hein batean behintzat" (346). Propietate horiek "seguru asko, neurri handi batean genetikoak dira, baina ez erabat" (347). Ez da harritzekoa horrek adostasunak egindako kritikak jaso izana (Barker 2010, Ereshefsky 2010, Lewens 2012, Leslie 2013, Slater 2013). Erantzun diet (argitaratzekoa).

Nire argudioaren ildoa honako hau da laburki. (1) Zergatik dauzkate afrikar errinozeroek bi adar eta indiar errinozeroek bat? Galdera horrek errinozero horien garapen-mekanismoen "egiturazko" azalpen bat (Kitcher 1984) eskatzen du. Eta, azken buruan, erantzuna bi errinozero-espezie horien oinarrizko izaera edo esentzia intrintsekoetan datza. Izaera horiek kausatzen dute bi errinozero-espezie horiek daukaten adar kopurua edukitzea. (2) Animaliatalde honetan, zergatik dauzka marrak horko horrek? Zebra delako eta zebren izaeran dagoelako marrak izatea: animalia horren azpiko propietate intrintsekoren batek egin zuen zebra eta kausatu zituen marrak. Hala, espezie baten (edo beste taxon baten) esentzia edo izaera da espezie horretako kideak, bere ingurunean, bere fenotipo-propietateak edukitzea kausatzen duen azpiko egoera intrintsekoa, zein-nahi dela ere, besterik ez; esentziak esplikatzen du 
organismo horiek lotura kausalean daukaten tokia espezieko kideak direlako soilik; "super-esplikatzailea" da esentzia, Antonella Mallozziren (2018) terminologia argian. ${ }^{40}$ Elliot Sober ondo ari da azpimarratzen duenean espezie baten esentziak izan behar duela "mekanismo kausal bat espezieko kide bakoitzarengan eragiten duena, den gauza klase egiten duena"; esentziak esplikatu behar du kideak zergatik "diren diren modukoak" ([1980] 1992: 250). Laburtzeko, esplikazio biologikoaren eskakizunek erakusten dute Kripke ondo ari dela esentzialismo intrintsekoari buruz, eta biologia-adostasuna oker.

Gero antzera argudiatu nuen badagoela, baita ere, osagai historiko bat espezie baten esentzian. Baina zer da osagai hori? Literaturan iradokitako erantzunen aurka argudiatzen dut, eta osagai historikoak osagai intrintseko bat eskatzen duela dioen ikuskeraren alde. Ezen espezie baten historia egokia klase intrintseko jakin bateko organismoena baita, beste klase intrintseko jakin bateko organismoetara eboluzionatuz, dagokigun espeziera iritsi arte. Hala, esentzialismo intrintsekoaren alde egiten du honek (2018a). ${ }^{41}$ Kripke bat etorriko litzateke agian. Argudio honek erreparatzen die espezie bateko kideak bere garapen-mekanismoak edukitzera nola iritsi ziren azaltzeko esplikazio "historikoen" eskakizunei (Kitcher 1984).

\section{Klase kimikoaren esentzialismoa}

Paul Needhamek kanpaina luzea darama Kripkeren eta Putnamen urari buruzko "mikroesentzialismo" aren kontra; ikus Needham (2011) eta aipatutako lehenagoko artikuluak. Kanpaina hori urari buruzko gertakari zientifikoen aurkezpen xehe eta argigarri batean oinarritzen da. Hala ere, ez dut uste arrakastarik daukanik. Kripkeri eragiten dionean soilik hartuko dut kontuan.

(1) Uraren esentzia gisa " $\mathrm{H}_{2} \mathrm{O}$ " $\mathrm{z}$ hitz egitea kritikatzen du Needhamek:

" $\mathrm{H}_{2} \mathrm{O}$ " adierazpenak uraren karakterizazio bat ematen du mikroegiturara jo gabe, eta uraren mikrodeskripzio bat eman nahi duen edozeinek miserableki huts egingo du " $\mathrm{H}_{2} \mathrm{O}$ " soilik eskainiz gero. (2011: 9)

Baina Kripkeren jarreraren erdigunean dago, esentziak/izaerak aurkitzeko, zientzia enpirikoei erreparatu behar diegula, ez bera bezalako filosofoei:

... zientzialariek ikertu dute urrearen izaera eta aurkitu dute 79 zenbaki atomikoa edukitzea substantzia horren izaeraren beraren parte dela, nolabait esan. (124)

40 Ikus, baita ere, Godman et al. (2020).

41 Marion Godman eta David Papineau (2020) ez datoz bat, eta esentzia guztiz historiko baten alde egiten dute beste ildo batzuetatik. Erantzun diet (2020: 19.5.2). 
gauza hori denari buruzko aurkikuntza zientifikoek (...), gaur egungo zientzia-teoriak dio guk ezagutzen dugun urrearen izaeraren parte dela 79 zenbaki atomikoa duen elementua izatea. (125)

Behiez, edo tigreez, propietate batzuk beharrezkoak direla zientziak enpirikoki aurki dezakeen ala ez beste galdera bat da; nik baietz erantzuten diot. (128)

Dudarik ez dago aurkikuntza bat dela ura $\mathrm{H}_{2} \mathrm{O}$ izatea. (128)

Beraz, uraren izaera $\mathrm{H}_{2} \mathrm{O}$ izateari buruzko Kripkeren jarduna, filosofian oso ohikoa den jarduna bestalde, ${ }^{42}$ filosofo baten gertakari zientifikoekiko begirune-keinu huts gisa ikusi behar da, besterik ez. Needhamen eztabaida gida lagungarria da gertakari horiek zein izan daitezkeen argitzeko. Limurtzailea da $\mathrm{H}_{2} \mathrm{O}$-jarduna desegokia dela, baina kimikaren beste filosofo baten, Robin Hendryren (argitaratzeko), duela gutxiko artikulu batek kontrakoa iradokitzen du.

Needhamek ez nau konbentzitzen dioenean Kripke oker dagoela pentsatzean esentzia erabat mikroa dela, baina, Kripke oker badago eta esentziaren parte bat, edo baita osoki ere, makroa balitz ere, hori soilik ez litzateke izango Kripkeren metafisikaren kontrako kolpe handia. Ziurra da Kripkek honezkero onartzen duela zientzia-klase askok esentzia makroak dauzkatela; harrapakari izan liteke adibide bat. Uraren esentzia propietate makroek osatzen dutela, erabiltzaile arruntek "ur" hitzari lotutako deskripzioek bereizitako propietate makroek osatzen dutela aurkitzea, hori izango litzateke benetako kolpea. Hori baita batez ere Kripke eta Putnam desafiatzen ari diren erreferentziaren deskripzio-teoriaren ondorioa: Putnamen leloaren hitz burutsuetan, "ur"en esanahia, "ez dago buruan, eta kito!". Needham ez da saiatzen desafio horri azpiak jaten.

(2) Needhamek salatzen du "ez d[ela] argudiorik eman baieztapen mikroesentzialistaren alde, zeinaren arabera ezaugarri mikroskopikoetara jo behar dugun substantzia baten ezaugarritze egokia lortzeko" (2011: 4). Needham oinarri sendoagoan dabil hemen: Kripkeren esentzialismoa intuizioetan oinarritzen da, azken finean. Intuitiboki argia iruditzen zaio berari —eta, esan beharra dugu, beste filosofo askori- urari, urreari eta antzekoei lotu ohi zaizkien propietateak, hiztegian jasotzen direnen modukoak, ez direla esentzialak haientzat, baina "barne-egitura" "atomiko"ren bat badela esentziala (119-29). Hala ere, intuizioetan oinarritze hori bekatua bada, bekatua nonahi dago filosofian; metafisikan, bereziki. Nolanahi ere, Kripkeren intuizioen alde argudia daiteke 6. atalean labur deskribatutako esentzialismo biologikoaren aldeko argudioaren ildo bertsuetan: lotu ohi zaizkion propietateak dauzka urak, eta bere zeregin kausala betetzen du munduan, azpiko propietate mikroskopiko

42 Ohikoa zen gogoaren "identitate teoria" ri buruzko eztabaidetan, esate baterako. 
batzuk edukitzeari esker; propietate hori super-esplikatzailea da. Eta horixe da, hain zuzen ere, Hendryk (argitaratzeko) argudiatzen duena. Mikroesentzialismoaren aldeko argudio horrek hipotesi enpiriko batean dauka oinarria, jakina. Uste dut hipotesi hori ikusi beharko genukeela Kripkeren intuizio esentzialisten atzean.

(3) Needhamek esaten du "estereotipikoa iduriko lukeen uraren ezaugarritze bat erraz eman daiteke[ela] urtze-puntua zehaztuz" (2011: 6). "Ez da beharrezkoa, beraz, ezaugarri mikroskopikoetara jotzea, beste substantzietatik bereizita uraren ezaugarritze egokia lortzeko" (2011: 7). Baina Needhamek buruan daukana "ezaugarritzea" da, Kripkek ez darabilen termino bat, eta Kripkek esentzia gisa buruan daukana baino askoz ahulagoa dirudiena. Kripke uraren izaeraren beraren atzetik dabil eta, inplizituki, nik uste, urari bere zeregin kausala ematen dion propietate esplikatzailearen atzetik. Ez litzateke gustura geldituko ura beste gauzetatik bereizi soilik egingo lukeen propietate batekin.

Azkenik, Sarah-Jane Leslieren (2013: 143-52) klase kimikoei buruzko eztabaidak Needhamen eragina islatzen du, baina beste kritika bat ere egiten du. Kripkeren eztabaida dena da urreari buruz eta urari buruz, Kripkeren bere aipuek, eta goiko nireek, adierazten dutenez. Baina Lesliek uste du "arrazoizkoa" dirudiela pasarte horietatik "inferitzea" "substantzia bera erlazioa"ren ikuskera bat (143), gero luze kritikatzen duena. Baina inferentzia hori ez da batere arrazoizkoa. Gauza bat da esatea zer den urrea edo ura izatea; beste gauza bat da esatea urrearentzat edo urarentzat edo beste edozerentzat "substantzia" bat izatea zer den; alegia, esatea zer den X eta Y gauzentzat "substantzia bera izatea". Antzera, gauza bat da esatea zer den tigre bat edo katu bat izatea; bestelako gauza bat da, erabat, esatea zer den tigreentzat edo katuentzat edo beste edozein taxonentzat "espezie" bat izatea; alegia, zer den esatea X eta Y taxonentzat "espezie bera" direla. ${ }^{43}$ Ez dut ikusten Kripkek substantzien auziaz (edo espezieen auziaz) jarrerarik hartu duelako ebidentziarik. Tuomas Tahko (2015) beste kritikoak ez bezala, ez dut ikusten ebidentziarik, ezta ere, Kripkek jarrera argirik hartu duenik urarentzat edo urrearentzat klase "kimiko" edo "natural" izatea zer den horri buruz.

\section{Esentzialismo indibiduala}

Zein da banako baten esentzia? Kripkek erantzun bat eskaintzen du banako biologikoentzat eta beste batzuentzat. Erantzun hori -bere "jatorri-esentzialismo" gisa ezagutzen denak— arreta handiz jarraitu dute

43 Lehena Ernst Mayrren "taxon-problema" da, bestea bere "kategoria-problema" (1982: 253-54). Mayrren bereizketa ondo onartua dago eta, hala ere, nik erakutsi dudanez (2008), bere garrantzia alde batera utzi ohi da, espezieei buruzko esentzialismo intrintsekoa baztertzean. 
metafisikariek (adibidez, McGinn (1976), Salmon (1979), Forbes (1986) eta Robertsonek (1998)). Biologiaren filosofoen atentzioa Kripkeren erantzunaren alderdi garrantzitsu bakar batera mugatu da, "Kidetza Esentzial" era. Doktrina horrek dio $O$ organismo bat taxon bateko, bereziki espezie bateko, kidea bada, orduan esentzialki dela horren kidea. Joseph LaPortek, biologiaren filosofo batek, auzia "sistematika biologikoaren argitan" landu nahi du eta salatzen du "esentzialistak kontu zientifikoetan xalo samarrak dir[ela]" (1997: 97). LaPorteren ikuspegiak Kidetza Esentziala arbuiatzera darama. Okashak (2002) bat egiten du LaPorteren arbuioarekin. ${ }^{44}$ Hala, LaPortek eta Okashak biek egiten dute Ori esentziala ez zaionari buruzko ikuskera baten alde, oinarri biologikotik. Baina ez beraiek, ez, nik aurki dezakedanaren heinean, beste ezein biologiaren filosofok edo ezein biologok heldu diote serioski Ori esentziala zaionari buruzko auziari, Kidetza Esentziala baino auzi zabalagoari. Badirudi auzi honek, metafisikariek asko eztabaidatu duten arren, ihes egin diola biologiaren filosofoen arretari. Duela gutxi eskaini diot arreta pixka bat nik, oinarri biologikotik baita ere (2018b).

Organismo jakin bat aintzat hartuz, ezaguna da Kripkek egindako galdera: "Erregina (...) jaio zitekeen egiazki etorki dituen gurasoak ez diren beste guraso batzuengandik?". Gurasotzat Erreginarengana eraman zuten "hazi eta obulu biologikoen iturriak diren gorputz-ehunak dituzten pertsonak" (112) ulertuta, ezezkoa da Kripkeren erantzuna: "beste jatorri batetik letorkeen edozer ez litzateke objektu hau izango" (113). Aurrera egiten du mahai jakin bati buruz antzeko galdera egiteko: "mahai hau beste egur-bloke batetik egin zitekeen, edo izotzean burutsu gogortutako urez...? (113). Ezezkoa da erantzuna beste behin (114). Proposatzen ari dena da, hortaz, "objektu baten jatorria esentziala zaiola dioen printzipioa" $(114,57$. oh.). Eta zer esan "eginda dagoen substantzia esentziala da" dioen printzipioaz? Kripkek onartzen du printzipio hori ere; hizpide genuen egurrezko mahaia ezin zitekeen "egurrez ez beste zerbaitez egina izan" (114-5, 57. oh.). Azkenik, Kripkek bi printzipioen arteko erlazio baten berri ematen du. Onartuz, Kripkek egiten duen bezala, mahaiaren etorkia den blokeari esentziala zaiola egurrezko blokea izatea, orduan, jatorri-printzipioaren arabera, esentziala zaio mahaiari egurrez egina izatea $\left(115,57\right.$. oh.). ${ }^{45}$

Jatorri-printzipioaren arabera, esentziala zaio Erreginari guraso jakin batzuengandik eta gameto jakin batzuetatik etortzea. Gameto horiek zigoto bat osatzeko batu ziren. Jatorri-printzipioaren arabera, esentziala zaio Erreginari

${ }^{44}$ LaPorteren argudioaren tankeragatik ondorioztatzen dut uste duela biologiaren filosofoek inplizituki arbuiatu zutela Kidetza Esentziala ordura arte. Ordutik esplizituki egin dute Griffith (1999), Levine (2001), Haber (2012), Leslie (2013) eta Witteveenek (2015).

45 Kripkek esaten du, baita ere, "(gutxi gorabehera) mahai bat izateak mahaiaren propietate esentziala dirudi"ela $(115,57$. oh.). Argudiatu dut iradokizun zuhur hori okerra dela (2005: 156). 
zigoto jakin horretatik etorri izana ere. Erreginari buruz esan duguna bere gurasoei aplikatzen zaie, jakina; eta haien gurasoei, eta abar. Oren esentziaren osagai historiko bat dago, beraz, pertsona indibidualek, gametoek eta zigotoek osatua, arbasoen historia hori, familia-zuhaitz hori egiten duena.

Kripkek ez dio substantzia-printzipioa aplikatzen Erreginari, baina guk aplika diezaiokegu. Mahaia esentzialki egurrezko materiala den bloke batetik datorren bezala, esentzialki giza materiala den zigoto batetik etorri behar du Erreginak. Kripkeren letrari ez bada izpirituari jarraiki, aurrerago jo behar dugu ziur asko Erreginaren substantziarekin: bere zigotoari, eta beraz Erreginari berari, esentziala zaiona ez da zigotoa nola-halako giza materialez soilik osatua egotea, baizik eta baita zigoto horren mota jakin horretakoaz ere. Hala, Kripkeren proposamena daukagu, zeinaren arabera Oren esentzia baita neurri batean gameto jakin batzuetatik, guraso jakin batzuengandik beraz, sortutako zigoto jakin bateko jatorria eta, beste neurri batean, Oren zigotoaren propietate intrintsekoak. ${ }^{46}$ Proposamen honen arabera, hortaz, Oren esentziak, 6. atalean proposatutako bere espeziearen esentziak bezala, osagai historikoa eta osagai intrintsekoa dauzka.

Bi proposamen hauek, Oren esentzia indibidualari buruzkoa eta bere espeziearen klase-esentziari buruzkoa, konbinatuta, Kidetza Esentzialaren alde argudiatu dut (2018b) (ez da zaila): Oren esentziaren osagai historikoak eta intrintsekoak edukitzeak Oren espeziearen esentziaren osagai historiko eta intrintsekoak edukitzea inplikatzen du (2018b).

Kripkeren banakoen esentzialismoaren aldeko sostengua intuizioetatik etorri da orain arte. Metodologiari buruzko galdera planteatzen du horrek. Okashak esaten du "onarpen zabala dutela" "esentzia indibidualari buruzko baiezpenek", "klase-esentziei" buruzkoek ez bezala, "ez diote[la] zientzia enpirikoari erantzuten"; "besaulkiko metafisikaria"rentzako kontuak direla, "intuizioei modalei (...) kasu eginda" landu beharrekoak (2002: 193). Laster oso laburki argudio bat deskribatuko dut, Kripkeren banako-esentzialismoak ere "zientzia enpirikoari erantzuten" diola erakusten duena. Hori ez da txarra ezen, dagoeneko esan dugun bezala, LaPortek eta biologiaren beste filosofo batzuek Kidetza Esentziala arbuiatzen baitute biologiako arrazoiengatik. Are gehiago, metafisikari guztiek ez dituzte Kripkeren intuizio esentzialista batzuk partekatzen.

Graeme Forbes (1986) eta Teresa Robertson (1998) metafisikari entzutetsuek neurri batean soilik egiten dute bat Kripkerekin bere esentzialismoaren osagai historikoari dagokionez. Aurkeztu dudan Kripkeren ikuskeran, gutxienez hiru erlazio zaizkio esentzialak Erreginari: (a) zigoto jakin batetik etorri behar du; (b) zigoto horrek gameto jakin batzuetatik etorri behar du; (c) ga-

${ }^{46}$ Hau organismo sexualez soilik da egia, jakina. 
meto horiek guraso jakin batzuengandik etorri behar dute. Forbesek eta Robertsonek ez diote eragozpenik jartzen (a)ri, baina bere intuizio modalek (b) ren eta (c)ren aurka egiten dute. Honela argudiatzen du Forbesek:

Demagun $h$ ernal-haziaren eta $o$ obuluaren fusioaz osatutako giza zigotoa dela $z$. Orduan, batek pentsa dezake zientzialariek zigoto bat sintetizatzen dutela nukleotidoz nukleotido eraikita, halako moldez non zren materia bera justu z-konfigurazio berean gertatzen baita. Mundu horretan, $h$ eta $o$ ez dira existitzen, edo hala postula dezakegu kontraesanik gabe, baina zaila da ukatzea $z$ existitzen dela (...) $z$ existitzen da, hortaz, baina jatorria ez du $h$ n eta on, ez baitira existitzen. (1986: 7)

Robertson bat dator eta esaten du gaiari buruz idazten duten beste batzuk ere bat datozela (1998: 732, 5. oh.). Ni ez nator bat: iruditzen zait sintetizatutako zigotoa ez dela $z$, hain zuzen, historia egokia falta duelako. ${ }^{47}$ Baina intuizioak baino gehiago behar dugu.

Banako-esentzialismo kripkearraren aldeko argudioak eskaintzen ditut, 6. atalean laburki deskribatutako taxon-esentzialismoaren aldekoen antzekoak direnak. Oren esentziaren osagai historikoa Oren esplikazio "historikoek" eskatzen dute; osagai intrintsekoa, berriz, "egiturazko" esplikazioek. Argudio horiek jatorri-esentzialismo kripkearra sostengatzen dute Forbes eta Robertsonen kontra, eta, espezie-esentzialismoarekin konbinatzen denean, Kidetza Esentziala sostengatzen dute biologiaren filosofoen kontra (2018b).

\section{Azkena}

Artikuluaren hasierako atalak Naming and Necessityko hizkuntzaren filosofiako eztabaidari buruzkoak ziren. 2. atalean, deskripzio-teorien aurkako Ezjakite eta Akatsaren argudioa eztabaidatu dut. Argudio hori suntsitzailea da izenen deskripzio-teorientzat, kausal-deskriptibistentzat barne. Baina deskripzio-teoria guztiei egiten die erronka, eta esanahiaren erabilpen-teoriari, eta beste gauza askori. Bere hedadurak eta indarrak ez dute merezi duten aitortza jaso.

3. atalean, "irudi" alternatiboaz jardun dut; teoria kausal-historikoaz. Kripkeren erreferentzia-mailegatzearen teoria da hizkuntzaren teoriari egindako bere beste ekarpen itzela. Oso gaizki ulertua izan da, hiztun bati eskatuko balio bezala, terminoa erabiltzean, terminoa jaso zuen pertsonari "eskuordetuz" egitea. Epistemikoki horren nekeza den "atzera begirako" asmoak

47 Honek saihesten du Robertson eta Atkinsek (2016) "Birziklatzearen problema" esaten diotena ederki: $z$ osatzen duen materia guztia kualitatiboki zren identikoa litzatekeen zerbaitetan birziklatuko balitz, ez litzateke $z$ izango hala ere, historia egokia faltako litzaiokeelako. 
ez dauka tokirik erreferentziaren "irudi" kripkearrean. Ikusteko geratzen da zehazki zenbateraino dagoen zabaldua hizkuntzan erreferentzia-mailegatzea.

4. atalean ikusi dugu deskripzio-teoria batek saihestu dezakeela Kripkeren Zurruntasun Galduaren argudioa bere deskripzioak zurrunduz. Hala ere, argudioa indartsua da deskripzio-teoria tradizional guztien aurka. Garrantzitsua da ohartzea erreferentziari buruzko intuizio horiek esentziala eta beharrezkoa denari buruzko intuizio metafisikoetatik eratortzen direla.

"Zurrun" termino singularrentzat definitzen da eta, hala ere, beste termino batzuei ere aplikatzen die Kripkek. Eztabaida dago horretarako zurruntasun-nozio egokia zein den. Schwartzen aurka argudiatu dut nozioarentzat nahi dugun zeregina ez dela klase "natural"en terminoak besteetatik bereiztea, Galdutako Zurruntasunaren argudioetan azaltzea baizik. Aplikazio zurrunaren nire nozioak ederki egiten du hori.

5. atalak erreferentzia zuzena du eztabaidagai. Izen baten esanahia bere erreferentea dela dioen teoria hedatu baina egiantzekotasun eskaseko hau Kripkeri bizkarreratzen zaio, baina berak, egiaz, ez du jarrerarik hartzen. Badirudi bizkarreratze oker horren arrazoia alternatibarik ez dagoelako ideia dela, behin izenaren esanahiari buruzko teoria deskriptibistak alde batera utzi direnean. Baina bada alternatiba bat, urteetan proposatzen aritu naizena: izen baten esanahia bere erreferentzia-modu kausala da. Erreferentzia zuzenaren historia bitxia kontatu dut, Kaplanen istorioarekin une gorenera iritsiz. Bera, Kripke ez bezala, bada izen propioen erreferentzia zuzenaren iturria eta, hala ere, duela gutxi proposatu du, izatez, nire alternatiba zaharra dena.

Azken hiru atalak Kripkeren esentzialismoari buruzko ikuskerez ari dira. Ikuskerok zorrozki kritikatu dituzte zientziaren filosofoek. Tigreena moduko klase biologikoek "barne-egitura" esentziala dutela dioen bere ikuskera, 6. atalean eztabaidatutakoa, baztertu egin dute biologiaren filosofoek, biologiari buruzko ezjakintasuna islatzen duelakoan. Eta urarena moduko klase kimikoei buruzko antzeko ikuskera bat, 7. atalean eztabaidatua, antzera baztertu du Paul Needham kimikaren filosofoak. Azkenik, 8. atalean, Kripkeren ikuskera, zeinaren arabera Erregina moduko banako batek parte batean historikoa den eta beste parte batean intrintsenkoa den esentzia baitauka, hartu dut aintzat. Kripkeren klase-esentzialismoarekin konbinatuta, horrek Kidetza Esentzialaren doktrinara darama: $O$ organismo indibidual bat espezie bateko kidea bada, esentzialki da horren kidea. Horrek beste behin biologiaren filosofoen aurka jartzen du Kripke. Eta metafisikari batzuk ere ez datoz bat berarekin "jatorri printzipioa" ri buruz.

Esentzialismo kripkearraren aurkako objekzio horiei erantzunez, gehienbat beste toki batzuetan egin ditudan argudio batzuei egin diet keinu. Argudio horiek honako hau daukate lehen premisa: klaseen edo banakoen behatutako propietateak esplikatzen dituzte esentziek, eta propietate horiek lotura 
kausaletan duten tokia ere bai. Zeregin kausala betetzen duen dena delakoa aurkituta, batek topatu du esentzia. Nire hipotesi enpirikoa da Kripke zuzen asko dagoela esentziei buruz. ${ }^{48}$

\section{Erreferentziak}

Ackerman, Felicia (Diana). 1979. "Proper Names, Propositional Attitudes and Non-Descriptive Connotations". Philosophical Studies 35: 55-69.

AlmoG, Joseph. 1984. "Semantic Anthropology". In French et al., 1984, 479-89.

Almog, Joseph. 1985. "Form and Content". Nous 19: 603-16.

Almog, Joseph, John Perry eta Howard Wettstein (arg.). 1989. Themes from Kaplan. Oxford: Oxford University Press.

BAKER, Lynne Rudder. 1982. "Underprivileged Access". Nous 16: 227-42.

BARKER, M. J. 2010. "Species Intrinsicalism". Philosophy of Science 77: 73-91.

BArwise, Jon eta John Perry. 1983. Situations and Attitudes. Cambridge, MA: MIT Press.

BIANCHI, Andrea (arg.). 2020a. Language and Reality from a Naturalistic Perspective: Themes from Michael Devitt. Cham: Springer.

BiANCHI, Andrea. 2020b. "Reference and Causal Chains". In Bianchi, 2020a, 121-36.

BIANCHI, Andrea eta Alessandro BonANINI. 2014. "Is There Room for Reference Borrowing in Donnellan's Historical Explanation Theory?". Linguistics and Philosophy 37: 175-203.

BlackBURN, Thomas. 1988. "The Elusiveness of Reference". In French et al., 1988, 179-94.

BLock, Ned. 1987. "Advertisement for a Semantics for Psychology". In French et al., 1987, 615-78.

Boer, Steven. 1985. "Substance and Kind: Reflections on the New Theory of Reference". In M. K. Matilal eta J. L. Shaw (arg.), Analytical Philosophy in Comparative Perspective. Dordrecht: D. Reidel, 103-50.

Braun, David. 2020. "Still for Direct Reference". In Bianchi 2020a: 193-235.

Cook, Monte. 1980. "If 'Cat' is a Rigid Designator, What Does it Designate?". Philosophical Studies 37: 61-64.

Davidson, Donald eta Gilbert Harman (arg.). 1972. Semantics of Natural Language. Dordrecht: D. Reidel.

DevitT, Michael. 1972. "The Semantics of Proper Names: A Causal Theory". Harvard PhD dissertation.

DeviTT, Michael. 1974. "Singular Terms". Journal of Philosophy LXXI: 183-205.

DeviTT, Michael. 1980. "Brian Loar on Singular Terms". Philosophical Studies 37: 271-80.

DeviTT, Michael. 1981a. Designation. New York: Columbia University Press.

DEviTT, Michael. 1981b. "Donnellan's Distinction". In French et al., 1981, 511-24.

DeviTT, Michael. 1985. Critical Notice of Evans' The Varieties of Reference 1982. Australasian Journal of Philosophy 63: 216-32.

DeviTT, Michael. 1989. "Against Direct Reference". In French et al., 1989, 206-40.

DevitT, Michael. 1996. Coming to Our Senses: A Naturalistic Program for Semantic Localism. Cambridge: Cambridge University Press.

48 Nire esker ona honako hauei zirriborro bati egindako iruzkinengatik: Andrea Bianchi, Ekain Garmendia, Kepa Korta, Saul Kripke, Antonella Mallozzi eta Panu Raatikainen. 
DeviTt, Michael. 2001. "A Shocking Idea about Meaning". Revue Internationale de Philosophie 208: 449-72.

DevitT, Michael. 2002. "Meaning and Use". Philosophy and Phenomenological Research 65: 106-21.

DevitT, Michael. 2004. "The Case for Referential Descriptions". In M. Reimer eta A. Bezuidenhout (arg.), Descriptions and Beyond. Oxford: Clarendon Press, 280-305.

DeviTT, Michael. 2005. "Rigid Application". Philosophical Studies 125: 139-65.

DevitT, Michael. 2008. "Resurrecting Biological Essentialism". Philosophy of Science 75: 344-82. Berrargitaratua, oin-ohar batzuk erantsita, in Devitt, 2010, 213-49.

DeviTT, Michael. 2010. Putting metaphysics first: essays on metaphysics and epistemology. Oxford: Oxford University Press.

DevitT, Michael. 2011a. "Deference and the Use Theory". ProtoSociology 27: 196-211.

DevitT, Michael. 2011b. "Experimental semantics". Philosophy and Phenomenological Research LXXXII: 418-35.

DeviTt, Michael. 2012a. "Whither Experimental Semantics?". Theoria 73: 5-36.

DevitT, Michael. 2012b. "Semantic Epistemology: Response to Machery". Theoria 74: 229-33.

DeviTT, Michael. 2012c. "Still Against Direct Reference". In R. Schantz (arg.), Prospects for Meaning. Berlin: Walter de Gruyter, 61-84.

DevitT, Michael. 2015. "Should Proper Names Still Seem So Problematic?". In A. Bianchi (arg.), On Reference. Oxford: Oxford University Press, 108-43.

DevitT, Michael. 2018a. "Historical Biological Essentialism". Studies in History and Philosophy of Biological and Biomedical Sciences 71: 1-7. DOI: 10.1016/j. shpsc.2018.05.004

DevitT, Michael. 2018b. "Individual Essentialism in Biology". Biology and Philosophy 33: 1-22. DOI: 10.1007/s10539-018-9651-1

DevitT, Michael. 2020. "Stirring the Possum: Responses to the Bianchi Papers". In Bianchi, 2020a, 371-455.

DevitT, Michael. argitaratzeko. "Defending Intrinsic Biological Essentialism". Philosophy of Science.

DevitT, Michael eta Nicolas Porot. 2018. "The Reference of Proper Names: Testing Usage and Intuitions". Cognitive Science 42: 1552-1585. doi.org/10.1111/ cogs.12609. doi.org/10.1111/cogs.12609

DevitT, Michael eta Kim Sterelny. 1999. Language and Reality: An Introduction to the Philosophy of Language, 2. edizioa. 1. edizioa, 1987. Oxford: Blackwell Publishers.

DickIE, Imogen. 2011. "How Proper Names Refer". Proceedings of the Aristotelian Society 101: 43-78.

Domaneschi, F., M. Vignolo eta S. Di Paola. 2017. "Testing the Causal Theory of Reference". Cognition 161: 1-9. doi.org/10.1016/j.cognition.2016.12.014

Donnellan, Keith S. 1966. "Reference and Definite Descriptions". Philosophical Review 75: 281-304.

Donnellan, Keith S. 1968. "Putting Humpty Dumpty Together Again". Philosophical Review 77: 203-15.

Donnellan, Keith S. 1972. "Proper Names and Identifying Descriptions". In Davidson eta Harman, 1972, 356-79.

DonNELlan, Keith S. 1974. "Speaking of Nothing". Philosophical Review 83: 3-31.

Donnellan, Keith S. 1983. "Kripke and Putnam on Natural Kind Terms". In C. Ginet eta S. Shoemaker (arg.), Knowledge and Mind. New York: Oxford University Press, 84-104. 
Donnellan, Keith S. 1989. "Belief and the Identity of Reference". In French et al., 1989, 275-88.

DummetT, Michael. 1973. Frege: Philosophy of Language. London: Duckworth.

Dupré, John. 1981. "Natural Kinds and Biological Taxa". Philosophical Review 90: 66-90.

ERESHEFSKY, Marc. 2010. "What's Wrong with the New Biological Essentialism". Philosophy of Science 77: 674-85.

Evans, Gareth. 1973. "The Causal Theory of Names". Proceedings of the Aristotelian Society, gehigarria 47: 187-208.

Evans, Gareth. 1982. The Varieties of Reference. John McDowell (arg.). Oxford: Clarendon Press.

Forbes, G. 1986. "In Defense of Absolute Essentialism". In French et al., 1986, 3-31.

French, Peter A., Theodore E. Uehling, Jr. eta Howard K. WetTstein (arg.). 1979. Contemporary Perspectives in the Philosophy of Language. Minneapolis: University of Minnesota Press.

French, Peter A., Theodore E. Uehling, Jr. eta Howard K. Wettstein (arg.). 1981. Midwest Studies in Philosophy Vol. 6, The Foundations of Analytic Philosophy. Minneapolis: University of Minnesota Press.

French, Peter A., Theodore E. Uehling, Jr. eta Howard K. Wettstein (arg.). 1984. Midwest Studies in Philosophy Vol. 9, Causation and Causal Theories. Minneapolis: University of Minnesota Press.

French, Peter A., Theodore E. Uehling, Jr. eta Howard K. Wettstein (arg.). 1986. Midwest Studies in Philosophy Vol. 11, Studies in Essentialism. Minneapolis, University of Minnesota Press.

French, Peter A., Theodore E. Uehling, Jr. eta Howard K. Wettstein (arg.). 1987. Midwest Studies in Philosophy Vol. 10, Studies in the Philosophy of Mind. Minneapolis: University of Minnesota Press.

French, Peter A., Theodore E. Uehling, Jr. eta Howard K. Wettstein (arg.). 1988. Midwest Studies in Philosophy Vol. 12, Realism and Antirealism. Minneapolis: University of Minnesota Press.

French, Peter A., Theodore E. Uehling, Jr. eta Howard K. Wettstein (arg.). 1989. Midwest Studies in Philosophy Vol. 14, Contemporary Perspectives in the Philosophy of Language II. Notre Dame: University of Notre Dame Press.

French, Peter A., Theodore E. Uehling, Jr. eta Howard K. Wettstein (arg.). 2007. Midwest Studies in Philosophy Vol. 31. Oxford: Blackwell Publishers.

Godman, Marion, Antonella Mallozzi eta David Papineau. 2020. "Essential Properties are Super-Explanatory: Taming Metaphysical Modality". Journal of the American Philosophical Association 6 (3): 316-34.

Godman, Marion eta David Papineau. 2020. "Species Have Historical not Intrinsic Essences". In Bianchi, 2020a, 355-67.

GRIFFITHS, Paul. 1999. "Squaring the Circle: Natural kinds with Historical Essences". In R. A. Wilson (arg.), Species: New Interdisciplinary Essays. Cambridge MA: MIT Press, 209-28.

Haber, M.H. 2012. "How to Misidentify a Type Specimen. Biology and Philosophy 27: 767-84.

HENDRY, Robin. (argitaratzeko). "How (not) to Argue for Microstructural Essentialism". Horwich, Paul. 1998. Meaning. Oxford: Oxford University Press.

Horwich, Paul. 2005. Reflections on Meaning. Oxford: Oxford University Press.

Horwich, Paul. 2020. "Languages and Idiolects". In Bianchi, 2020a, 285-96. 
IChikaWA, J., I. Maitra eta B. Weatherson. 2012. "In Defense of a Kripkean Dogma". Philosophy and Phenomenological Research 85 (1): 56-68. https://doi.org/10.1111/j.1933 -1592.2010.00478.x

JACKSON, Frank. 1998. From Metaphysics to Ethics. Oxford: Clarendon Press.

JACKSON, Frank. 2020. "Language from a Naturalistic Perspective". In Bianchi, 2020a, $155-71$.

KaPLAn, David. 1978. "Dthat". In P. Cole (arg.), Syntax and Semantics 9: Pragmatics. New York: Academic Press, 221-43.

Kaplan, David. 1989a. "Demonstratives: An Essay on the Semantics, Logic, Metaphysics, and Epistemology of Demonstratives and Other Indexicals". In Almog, Perry eta Wettstein, 1989, 510-63.

KaPLAN, David. 1989b. "Afterthoughts". In Almog, Perry eta Wettstein, 1989, 565-614.

KAPLAN, David. 2012. "An Idea of Donnellan". In J. Almog eta P. Leonardi (arg.), Having in Mind: The Philosophy of Keith Donnellan. New York: Oxford University Press, 122-75.

KITCHER, Philip. 1984. "Species". Philosophy of Science 51: 308-33.

KRIPKE, Saul A. 1972. "Naming and Necessity". In Davidson eta Harman, 1972, 253-355.

KRIPKE, Saul A. 1980. Naming and Necessity. Cambridge, MA: Harvard University Press.

Kroon, Frederick. 1987. "Causal Descriptivism". Australasian Journal of Philosophy 65: $1-17$.

LAPORTE, Joseph. 1997. "Essential Membership". Philosophy of Science 64: 96-112.

LAPORTE, Joseph. 2000. "Rigidity and Kind". Philosophical Studies 97: 293-316.

Lepore, Ernest eta Barry Loewer. 1987. "Solipsistic Semantics". In French et al., 1987, 595-614.

LESLIE, Sarah-Jane. 2013. "Essence and Natural Kinds: When Science Meets Preschooler Intuition". In T. S. Gendler eta J. Hawthorne (arg.), Oxford Studies in Epistemology Volume 4. Oxford: Oxford University Press, 108-65.

LEWENS, T. 2012. "Species Essence and Explanation". Studies in History and Philosophy of Biological and Biomedical Sciences 43: 751-57.

Levine, A. 2001. "Individualism, Type Specimens, and the Scrutability of Species Membership". Biology and Philosophy 16: 325-38.

LeWIS, David. 1984. "Putnam's Paradox". Australasian Journal of Philosophy 62: 221-36.

LOAR, Brian. 1976. "The Semantics of Singular Terms". Philosophical Studies 30: 353-77.

LuDwig, K. 2007. "The Epistemology of Thought Experiments: First-Person Approach vs. Third-Person Approach". In Midwest Studies in Philosophy 31: 128-59. https:// doi.org/10.1111/j.1475-4975.2007.00160.x.

LyCAN, William G. 1985. "The Paradox of Naming". In B. K. Matilal eta J. L. Shaw (arg.), Analytical Philosophy in Comparative Perspective. Dordrecht: D. Reidel, 81-102.

Масветн, Danielle. 1995. "Names, Natural Kind Terms, and Rigid Designation". Philosophical Studies 79: 259-81.

MCGINN, Colin. 1976. "On the Necessity of Origin". Journal of Philosophy 73: 127-35.

MCGINN, Colin. 1982. "The Structure of Content". In A. Woodfield (arg.), Thought and Object. Oxford: Clarendon Press, 207-58.

McKay, Tom. 1981. "On Proper Names in Belief Ascriptions". Philosophical Studies 39: 287-303.

MACHERY, E. 2012a. "Expertise and Intuitions about Reference". Theoria 73: 37-54. https://doi.org/theoria20122712

MACHERY, E. 2012b. "Semantic Epistemology: A Brief Response to Devitt". Theoria 74: 223-27. https://doi.org/10.1387/theoria.6223 
Machery, E., R. Mallon, S. Nichols eta S. P. Stich. 2004. "Semantics, Cross-Cultural Style". Cognition 92 (3): 1-12. https://doi.org/10.1016/j.cognition.2003.10.003

Machery, E., R. Mallon, S. Nichols eta S. P. Stich. 2013. "If Folk Intuitions Vary, Then What?". Philosophy and Phenomenological Research 86 (3): 618-35. https://doi.org /10.1111/j.1933-1592.2011.00555.x

Machery, E., C. Y. Olivola eta M. de Blanc. 2009. "Linguistic and Metalinguistic Intuitions in the Philosophy of Language". Analysis 69 (4): 689-94. https://doi.org /10.1093/analys/anp095

MACHERY, E. eta S. P. STiCH. 2012. "The Role of Experiments". In G. Russell eta D. Graff Fara (arg.), The Routledge Companion to Philosophy of Language. New York: Routledge, 495-512.

MaLlozzI, Antonella. 2018. "Putting Modal Metaphysics First". Synthese. https://doi. org/10.1007/s11229-018-1828-2

MarCuS, Ruth Barcan. 1961. "Modalities and Intensional Language". Synthese 13: 303-22.

MARTí, Genoveva. 2009. "Against Semantic Multi-Culturalism”. Analysis 69 (1): 42-48. https://doi.org/10.1093/analys/ann007

MARTí, Genoveva. 2012. "Empirical Data and the Theory of Reference". In W. P. Kabasenche, M. O'Rourke eta M. H. Slater (arg.), Reference and Referring. Topics in Contemporary Philosophy. Cambridge, MA: MIT Press, 62-76.

MAYR, Ernst. 1982. The Growth of Biological Thought. Cambridge, MA: Harvard University Press.

MerCIER, Adèle. 1999. “On Communication-Based De Re Thought, Commitments De Dicto, and Word-Individuation". In K. Murasugi eta R. Stainton (arg.), Philosophy and Linguistics. Boulder, CO: Westview Press, 85-111.

Mondadori, Fabrizio. 1978. "Interpreting Modal Semantics". In F. Guenther eta C. Rohrer (arg.), Studies in Formal Semantics. Amsterdam: North-Holland Publishing Co., 13-40.

Needham, Paul. 2011. "Microessentialism: What is the Argument?". Nous 45: 1-21.

ОкаSна, S. 2002. "Darwinian Metaphysics: Species and the Question of Essentialism". Synthese 131: 191-213.

Pustejovsky, James. 1995. The Generative Lexicon. Cambridge, Mass.: MIT Press.

Putnam, Hilary. 1973. "Meaning and Reference". Journal of Philosophy LXX: 699-711.

Putnam, Hilary. 1975. Mind, Language and Reality: Philosophical Papers, Volume 2. Cambridge: Cambridge University Press.

Putnam, Hilary. 1978. Meaning and the Moral Sciences. London: Routledge \& Kegan Paul.

PUTNAM, Hilary. 2001: "Reply to Devitt". Revue Internationale de Philosophie 208: 495-502.

RaAtikainen, Panu. 2020. "Theories of Reference: What Was the Question?". In Bianchi, 2020a, 69-103.

RoberTsOn, T. 1998. "Possibilities and the Arguments for Origin Essentialism". Mind 107: 729-49.

Robertson, T. eta P. Atkins. 2016. "Essential vs Accidental Properties". In E. Zalta (arg.), The Stanford Encyclopedia of Philosophy (Summer 2016 Edition) https:// platostanfordedu/archives/sum2016/entries/essential-accidental/

RusE, Michael. 1987. "Biological Species: Natural Kinds, Individuals, or What?". British Journal for the Philosophy of Science 38: 225-42. Berrargitaratua in M. Ereshefsky (arg.), The Units of Evolution: Essays on the Nature of Species. Cambridge, MA: MIT Press, 343-61. [Aipua Ereshefsky 1992koa da.]

SALMON, Nathan. 1979. "How not to Derive Essentialism". Journal of Philosophy 76: 703-25. 
SALmon, Nathan. 1986. Frege's Puzzle. Cambridge, MA: MIT Press.

SALMON, Nathan. 2020. "Naming and Non-Necessity". In Bianchi, 2020a, 237-48.

SCHIFFER, Stephen. 1979. "Naming and Knowing". In French et al., 1979, 61-74.

SchwarTz, Stephen P. 1977. "Introduction". In S. P. Schwartz (arg.), Naming, Necessity, and Natural Kinds. Ithaca: Cornell University Press, 13-41.

Schwartz, Stephen P. 1980. "Formal Semantics and Natural Kind Terms". Philosophical Studies 38: 189-98.

SCHWARTZ, Stephen P. 2002. "Kinds, General Terms, and Rigidity". Philosophical Studies 109: 265-77.

Schwartz, Stephen P. 2020. "Against Rigidity for General Terms". In Bianchi, 2020a, 249-66.

SEARLE, John R. 1958. "Proper Names". Mind 67: 166-73.

SEARLe, John R. 1983. Intentionality: An Essay in the Philosophy of Mind. Cambridge: Cambridge University Press.

Slater, M. H. 2013. Are Species Real? An Essay on the Metaphysics of Species. New York: Palgrave Macmillan.

SOAMES, Scott. 1985. "Lost Innocence". Linguistics and Philosophy 8: 59-71.

SoAmES, Scott. 1987. "Direct Reference, Propositional Attitudes, and Semantic Content". Philosophical Topics 15: 47-87.

SoAmes, Scott. 2002. Beyond Rigidity: The Unfinished Semantic Agenda of Naming and Necessity. New York: Oxford University Press.

Sober, Elliott. 1980. "Evolution, Population Thinking and Essentialism". Philosophy of Science 47: 350-83. Berrargitaratua in M. Ereshefsky (arg.), The Units of Evolution: Essays on the Nature of Species. Cambridge, MA: MIT Press, 247-78. [Aipua Ereshefsky 1992koa da.]

Sterelny, Kim eta Paul Griffiths. 1999. Sex and Death. Chicago: University of Chicago Press.

Strawson, P. F. 1959. Individuals: An Essay in Descriptive Metaphysics. London: Methuen.

Sullivan, Arthur. 2010. "Millian Externalism". In R. Jeshion (arg.), New Essays on Singular Thought. Oxford: Oxford University Press, 246-69.

Sytsma, J., eta J. Livengood. 2011. "A New Perspective Concerning Experiments on Semantic Intuitions". Australasian Journal of Philosophy 89 (2): 315-32. https://doi. org/10.1080/00048401003639832

Танко, Tuomas E. 2015. "Natural Kind Essentialism Revisited". Mind 124: 795-822.

TYE, Michael. 1978. "The Puzzle of Hesperus and Phosphorus". Australasian Journal of Philosophy 56: 219-24.

WaGner, Steven J. 1986. "California Semantics Meets the Great Fact". Notre Dame Journal of Formal Logic 27: 430-55.

Weinberg, J. M., C. Gonnerman, C. Buckner eta J. Alexander. 2010. "Are Philosophers Expert Intuiters?". Philosophical Psychology 23 (3): 331-55. https://doi.org/10.1080 /09515089.2010.490944

WetTstein, Howard. 1986. "Has Semantics Rested on a Mistake?". Journal of Philosophy LXIII: 185-209.

WetTstein, Howard. 2012. "On Referents and Reference Fixing". In R. Schantz (arg.), Prospects for Meaning. Berlin: Walter de Gruyter, 107-18.

WitteveEn, J. 2015. "Naming and Contingency: The Type Method of Biological Taxonomy". Biology and Philosophy 30: 569-86. doi: 101007/s10539-014-9459-6 